\title{
Using freezing spectra characteristics to identify ice-nucleating particle populations during the winter in the Alps
}

\author{
Jessie M. Creamean ${ }^{1,2, a}$, Claudia Mignani ${ }^{3}$, Nicolas Bukowiecki ${ }^{4, b}$, and Franz Conen ${ }^{3}$ \\ ${ }^{1}$ Cooperative Institute for Research in Environmental Sciences, University of Colorado, Boulder, CO, USA \\ ${ }^{2}$ Physical Sciences Division, National Oceanic and Atmospheric Administration, Boulder, CO, USA \\ ${ }^{3}$ Department of Environmental Sciences, University of Basel, Basel, Switzerland \\ ${ }^{4}$ Laboratory of Atmospheric Chemistry, Paul Scherrer Institute, Villigen, Switzerland \\ ${ }^{a}$ now at: Department of Atmospheric Science, Colorado State University, Fort Collins, CO, USA \\ ${ }^{b}$ now at: Department of Environmental Sciences, University of Basel, Basel, Switzerland
}

Correspondence: Jessie M. Creamean (jessie.creamean@ colostate.edu)

Received: 12 October 2018 - Discussion started: 12 November 2018

Revised: 28 May 2019 - Accepted: 29 May 2019 - Published: 21 June 2019

\begin{abstract}
One of the least understood cloud processes is modulation of their microphysics by aerosols, specifically of cloud ice by ice-nucleating particles (INPs). To investigate INP impacts on cloud ice and subsequent precipitation formation, measurements in cloud environments are necessary but difficult given the logistical challenges associated with airborne measurements and separating interstitial aerosol from cloud residues. Additionally, determining the sources of INPs is important given the dependency of glaciation temperatures on the mineral or biological components and diversity of such INP populations. Here, we present results from a comparison of INP spectral characteristics in air, cloud rime, and fresh fallen snow at the High Altitude Research Station, Jungfraujoch. The goal of the study was twofold: (1) to assess variability in wintertime INP populations found in cloud based on wind and air mass direction during snowfall and (2) to evaluate possible INP sources between different sample types using a combination of cumulative INP $(K(T))$ and differential INP $(k(T))$ spectra. INP freezing temperatures and concentrations were consistently higher on average from the southeast as compared to the northwest for rime, snow, and especially aerosol samples, which is likely a result of air mass influence from predominantly boundary layer terrestrial and marine sources in southern Europe, the Mediterranean, and North Africa. For all three sample types combined, average onset freezing temperatures were -8.0 and $-11.3^{\circ} \mathrm{C}$ for southeasterly and northwesterly days, respectively, while $K(T)$ were 3 to 20 times
\end{abstract}

higher when winds arrived from the southeast. Southeasterly aerosol samples typically had a clear mode in the warmtemperature regime (i.e., $\geq-15^{\circ} \mathrm{C}$ ) in the $k(T)$ spectra - indicating a putative influence from biological sources - while the presence of a warm mode in the rime and snow varied. Evaluating $K(T)$ concert with $k(T)$ spectra exhibited variable modality and shape - depending on the types of INPs present - and may serve as a useful method for comparing different sampled substances and assessing the possible relative contributions of mixed mineral and biological versus only biological INP sample populations.

\section{Introduction}

Aerosols are key players in the atmospheric radiation budget, cloud microphysics, and precipitation development. Aerosolinduced ice microphysical modifications influence cloud lifetime and albedo (Albrecht, 1989; Twomey, 1977; Storelvmo et al., 2011), as well as the production of precipitation (DeMott et al., 2010). Mixed-phase clouds (MPCs) are ubiquitous in the troposphere over the entire annual cycle yet are difficult to quantify globally in part due to an inadequate understanding of aerosol-cloud interactions in mixed-phase environments (Korolev et al., 2017). Thus, a close evaluation of aerosol-cloud processes is crucial to evaluating weather and climate processes. However, one of the most significant challenges with regard to aerosols is quantifying their impacts on 
cloud ice formation through serving as ice-nucleating particles (INPs) (Boucher et al., 2013). Constraining aerosolcloud impacts in models, specifically when parameterizing INPs in MPC systems, remains a significant challenge due to limited observations (Cziczo et al., 2017; Coluzza et al., 2017; DeMott et al., 2010; Kanji et al., 2017; Korolev et al., 2017). Observations directly in cloud are even more scarce - given the logistical costs and resources required by airborne platforms, caveats associated with aircraft probes and instrumentation, and instrumental artefacts caused by flying through clouds at high speeds (Cziczo et al., 2017) - but are useful for assessing the impacts of INPs on MPC microphysics as compared to most surface measurements which are geared towards evaluation of INP sources.

In the absence of conditions with $-38^{\circ} \mathrm{C}$ and relative humidity with respect to ice above $140 \%$, INPs are required for initiation of tropospheric cloud ice formation (Kanji et al., 2017). Aerosols such as dust and primary biological aerosol particles (PBAPs) are some of the most abundant and efficient INPs found in the atmosphere, respectively (Murray et al., 2012; Hoose and Möhler, 2012; DeMott et al., 1999; Conen et al., 2011; Creamean et al., 2013). PBAPs originating from certain bacteria, pollens, and vegetative detritus are the most efficient INPs known, capable of initiating freezing near $-1{ }^{\circ} \mathrm{C}$, while most PBAPs (e.g., fungal spores, algae, and diatoms) tend to nucleate ice at temperatures similar to those of mineral dust (Despres et al., 2012; Murray et al., 2012; Tobo et al., 2014; Hader et al., 2014; O'Sullivan et al., 2014; Hill et al., 2016; Tesson et al., 2016; Alpert et al., 2011; Knopf et al., 2010; Fröhlich-Nowoisky et al., 2015). In general, previous works collectively indicate that PBAP INPs that nucleate ice at temperatures greater than approximately $-10{ }^{\circ} \mathrm{C}$ are bacterial (Murray et al., 2012; Hu et al., 2018; Hoose and Möhler, 2012; Despres et al., 2012; Fröhlich-Nowoisky et al., 2016) but could also be pollen or certain fungal spores (von Blohn et al., 2005; Hoose and Möhler, 2012; O'Sullivan et al., 2016), although the latter two are less likely. Plant bacteria such as Pseudomonas syringae are deemed omnipresent in the atmosphere and precipitation (Despres et al., 2012; Stopelli et al., 2017; Morris et al., 2014) and facilitate cloud ice formation up to $-1{ }^{\circ} \mathrm{C}$ (Despres et al., 2012). Only a few laboratory-based studies have reported known inorganic or mineral materials with ice nucleation activity at such temperatures (Ganguly et al., 2018; Atkinson et al., 2013). Mineral and soil dust serving as atmospheric shuttles for organic microbial fragments can be transported thousands of kilometers and serve as effective INPs, even from highly arid regions such as the Sahara (Kel$\operatorname{logg}$ and Griffin, 2006). The origin of the ice nucleation germ forming at the warmest temperatures is thought to be due to the ice binding proteins or macromolecules of the biological components in mixed mineral-biological INPs (O'Sullivan et al., 2014, 2016; Conen and Yakutin, 2018). In general, the previous studies on the climate relevance of PBAPs demonstrate the importance of such INPs at MPC temperatures and precipitation enhancement (Morris et al., 2004, 2014, 2017; Bergeron, 1935; Christner et al., 2008; Stopelli et al., 2014; Fröhlich-Nowoisky et al., 2016).

Although biological constituents, from cellular material to intact bacteria and spores, are thought to be omnipresent in the atmosphere (Burrows et al., 2009a, b; Jaenicke, 2005; Jaenicke et al., 2007), modeling studies constraining global emission estimates of biological INPs and PBAPs are very limited, subject to significant hurdles, and often yield conflicting results due to not having a sufficient set of observations and complexity of atmospheric PBAPs (Hummel et al., 2015; Burrows et al., 2013; Twohy et al., 2016; FröhlichNowoisky et al., 2012; Despres et al., 2012; Hoose and Möhler, 2012; Morris et al., 2011). Yet, biological aerosols such as bacteria have been shown to cause significant perturbations in cloud ice in numerical weather prediction models, affording modulations in cloud radiative forcing and precipitation formation (Sahyoun et al., 2017). In addition, measuring and quantifying PBAPs is nontrivial - methodologies for counting, culturing, and nucleic-acid sequencing of PBAPs and especially for those which fall in the warm-temperature INP regime (i.e., INPs that nucleate ice $>-15^{\circ} \mathrm{C}$ ) are (1) time and labor intensive, (2) require specific expertise or at times substantial resources, (3) require substantial sample volumes, or (4) are species- or generaspecific or limited to viable microorganisms (Despres et al., 2012). Although such techniques are required to adequately assess the atmospheric microbiome and PBAP sources, a simpler approach could be applied to evaluate and even quantify warm-temperature biological INP populations as compared to colder temperature PBAPs or mineral dust.

The objectives of the study presented here are (1) to conduct an comparison of INP measurements of aerosol, cloud rime, and snow directly in cloud and (2) to evaluate different types of INP spectra in a manner such that we can estimate the relative contribution from biological INPs in the warm-temperature regime relevant to MPCs. A secondary goal is to assess the variability in INP spectra and possible sources from different dominant air mass transport directions observed during sample collection under the current study. Sampling was conducted at the High Altitude Research Station Jungfraujoch (JFJ), a unique location for evaluating populations of INPs that affect winter storms in the European Alps, and where MPCs are particularly common (Lohmann et al., 2016). Recent studies at JFJ have provided valuable insight into INP concentrations, sources, and removal processes under a variety of conditions and during various times of the year. Conen et al. (2015) measured INPs at $-8^{\circ} \mathrm{C}$ over the course of a year at JFJ and found a strong seasonality in such INPs, with 2 orders of magnitude higher concentrations observed during the summer. They also suggested INPs measured at this temperature may be limited most of the year by microphysical processing during transit. Stopelli et al. (2015) verified this removal mechanistic process through INP measurements and isotopic composition of fresh fallen snow at 
JFJ, concluding that warm-temperature INPs are rapidly depleted by precipitating clouds at lower elevations. Stopelli et al. (2016) expanded their INP analyses to 2 years of data at JFJ, concluding that a high abundance of INPs at $-8^{\circ} \mathrm{C}$ is to be expected whenever high wind speed coincides with air masses having experienced little or no precipitation prior to sampling, yet a separate study by Stopelli et al. (2017) found that only a small fraction of the INPs were cultivable cells of Pseudomonas syringe. In contrast, Lacher et al. (2018a, b) conducted an interannual synopsis of INP measurements at JFJ and found anthropogenic influence on INP concentrations but only during boundary layer intrusion (BLI) and at relatively cold temperatures (i.e., approximately $-30^{\circ} \mathrm{C}$ ), as well as higher INP concentrations during Saharan dust events (SDEs) and marine boundary layer air arriving at JFJ. Eriksen Hammer et al. (2018) characterized ice particle residuals and concluded that silica and aluminosilicates were the most important ice particle residuals at JFJ during the mixed-phase cloud events during January-February 2017, while carbonrich particles of possible biological origin were a minor contribution.

Here, we demonstrate how variable sources influence INP populations depending on air mass transport and direction, and spectral modality between the rime, snow, and aerosols can help explain the exchange of INPs from air into cloud and then into precipitation. Our results expand upon previous studies by evaluating INPs via a combination of aerosol, rime, and snow and at a temperature range that comprises common biological and mineral INPs.

\section{Methods}

\subsection{Aerosol, cloud rime, and snow collection at Jungfraujoch}

Collocated collection of snow, cloud rime, and aerosol samples for the Ice Nucleation Characterization in the Alps of Switzerland (INCAS) study took place from 15 February to 11 March 2018 in the Sphinx observatory at JFJ $\left(46.55^{\circ} \mathrm{N}, 7.98^{\circ} \mathrm{E} ; 3580 \mathrm{~m}\right.$ above sea level (m a.s.1.); https: //www.hfsjg.ch/en/home/, last access: August 2018). Snow was collected as described by Stopelli et al. (2015) using a Teflon-coated tin $\left(0.1 \mathrm{~m}^{2}, 8 \mathrm{~cm}\right.$ deep) for a duration of 1$18 \mathrm{~h}$ but typically for $1-4 \mathrm{~h}$. Collection quantities and time of collection were dependent upon snowfall rates but additionally on winds blowing snow out of the collection pans. Because of this possibility, we cannot determine actual snowfall rates with certainty. Cloud rime was collected using a slotted plexiglass plate placed vertically during snow sample collection (Lacher et al., 2017; Mignani et al., 2019). Sample collection times were at times longer than the duration of in-cloud conditions (see Sect. 2.3) and were dependent on when manually changing the sampling tin and plate was possible. Daily size-resolved aerosol samples were collected using a Davis Rotating-drum Universal-size-cut Monitoring (DRUM) single-jet impactor (DA400, DRUMAir, LLC.) (Cahill et al., 1987; Bukowiecki et al., 2009; Creamean et al., 2018a) from a $1 \mathrm{~m}$ long inlet constructed of $6.4 \mathrm{~mm}$ inner diameter static-dissipative polyurethane tubing (McMasterCarr $^{\circledR}$ ) leading to outside of the Sphinx and connected to a funnel covered with a loose, perforated plastic bag to prevent rime ice buildup or blowing snow from clogging the inlet. The DRUM collected aerosol particles at four size ranges $(0.15-0.34,0.34-1.20,1.20-2.96$, and 2.96-> $12 \mu \mathrm{m}$ in diameter) and sampled at $27.7 \mathrm{~L} \mathrm{~min}^{-1}$ (volumetric flow), equalling 39888 total liter of air per sample. Such size ranges cover a wide array of aerosols - particularly those that serve as INPs (DeMott et al., 2010; Fridlind et al., 2012; Mason et al., 2016) - while the large volume of air collected promotes collection of rarer, warm-temperature biological INPs but may represent a lower fraction of overall INP concentrations (Mossop and Thorndike, 1966). Samples were deposited onto $20 \mathrm{~mm} \times 190 \mathrm{~mm}$ strips of petrolatum-coated $\left(100 \%\right.$, Vaseline $\left.{ }^{\circledR}\right)$ perfluoroalkoxy plastic (PFA, $0.05 \mathrm{~mm}$ thick) substrate secured onto the rotating drums $(20 \mathrm{~mm}$ thick, $60 \mathrm{~mm}$ in diameter) in each of the four stages at the rate of $7 \mathrm{~mm} \mathrm{~d}^{-1}(5 \mathrm{~mm}$ of sample streaked onto the PFA followed by $2 \mathrm{~mm}$ of blank). It is possible local sources of aerosol, such as tobacco smoke or emissions from touristic infrastructure, were collected by the DRUM (Bukowiecki et al., 2016) but did not likely affect the $2.96->12 \mu \mathrm{m}$ particles which we focus on herein. Intervals in which snow, rime, and aerosol were sampled did not fully overlap during a day because conditions were changing often unpredictably between out-of-cloud and in-cloud conditions, the latter with or without precipitation. At the same time we intended to collect enough material from either component for a robust analysis of warm-temperature INPs. Consequently, the combined data of a day integrate over a larger air mass, including clouds and cloud-free regions. Comparing data from snow, rime, and aerosol samples still makes sense as long as wind direction and the influence of planetary boundary layer did not change substantially during a day.

\subsection{Ice nucleation measurements}

All samples were analyzed immediately after collection for INPs using a drop freezing cold plate (DFCP) system described by Creamean et al. (2018a, b). Briefly, snow and cloud rime samples were melted into covered $50 \mathrm{~mL}$ glass beakers for analysis, resulting in approximately $10 \mathrm{~mL}$ of liquid per sample. Samples were manually shaken prior to analysis. Aerosols deposited onto the PFA were prepared for drop freezing by cutting out each daily sample and placing it in a $50 \mathrm{~mL}$ glass beaker with $2 \mathrm{~mL}$ of molecular biology reagent grade water (Sigma-Aldrich $\left.{ }^{\circledR}\right)$. Beakers were covered and shaken at $500 \mathrm{rpm}$ for $2 \mathrm{~h}$ (Bowers et al., 2009). In between sampling, beakers were cleaned with isopropanol 
$(99.5 \%)$, sonicated with double-distilled water for $30 \mathrm{~min}$, and then heated at $150^{\circ} \mathrm{C}$ for $30 \mathrm{~min}$.

Copper discs $(76 \mathrm{~mm}$ in diameter, $3.2 \mathrm{~mm}$ thick) were prepared by sonicating in double-distilled water for $30 \mathrm{~min}$, cleaning with isopropanol, and then coated with a thin layer of petrolatum (Tobo, 2016; Bowers et al., 2009). Following sample preparation, a sterile, single-use syringe was used to draw $0.25 \mathrm{~mL}$ of the suspension, and 100 drops were pipetted onto the petrolatum-coated copper disc, creating an array of $\sim 2.5 \mu \mathrm{L}$ aliquots. Drops were visually inspected for size; however, it is possible not all drops were the same exact volume, which could lead to a small level of uncertainty (Hader et al., 2014; Bigg, 1953; Langham and Mason, 1958; Creamean et al., 2018b). The copper disc was then placed on a thermoelectric cold plate $\left(\right.$ Aldrich $^{\circledR}$ ) and covered with a transparent plastic dome. Small holes in the side of the dome and copper disc permitted placement of up to four temperature probes using an Omega ${ }^{\mathrm{TM}}$ thermometer and data logger (RDXL4SD; $0.1^{\circ} \mathrm{C}$ resolution and accuracy of $\pm\left(0.4 \%+1{ }^{\circ} \mathrm{C}\right)$ for the $\mathrm{K}$ sensor types used $)$. During the test, the cold plate was cooled at $1-10^{\circ} \mathrm{C} \mathrm{min}-1$ from room temperature until around $-35^{\circ} \mathrm{C}$. Control experiments at various cooling rates within this range show very little discernible dependency of drop freezing on cooling rate (Creamean et al., 2018b), akin to previous works (Wright and Petters, 2013; Vali and Stansbury, 1966).

A $+0.33{ }^{\circ} \mathrm{C}$ correction factor was added to any temperature herein, and an uncertainty of $0.15^{\circ} \mathrm{C}$ was added to the probe accuracy uncertainty based on DFCP characterization testing presented in Creamean et al. (2018b), to account for the temperature difference between the measurement (i.e., in the plate center) and actual drop temperature. Frozen drops were detected visually but recorded through custom software. The software records the time, probe temperature, and cooling rate for every second of the test. When a drop is identified as frozen, a button is clicked on the software graphical user interface so that it records that exact time, probe temperature, and cooling rate of that drop in a separate file. The test continued until all 100 drops were frozen. Each sample was tested three times with 100 new drops for each test. The fraction frozen was calculated from all detected drops frozen combined from the three tests (typically $>90 \%$ of the drops were detected). The results from the triplicate tests were then binned every $0.5^{\circ} \mathrm{C}$ to produce one spectrum per sample. $\mathrm{Cu}$ mulative INP concentrations were calculated using the equation from Vali (1971):

$K(T)=-\frac{1}{V_{\text {drop }}} \times \ln [1-f(T)]$,

where $V_{\text {drop }}$ is the volume of each drop and $f(T)$ is the fraction of drops frozen at temperature $T$. Aerosol cumulative INP concentrations were corrected for the total volume of air per sample $\left(K(T) \times \frac{V_{\text {suspension }}}{V_{\text {air }}}\right)$ while melted rime/snow residual cumulative INPs were adjusted to the total used during analysis $\left(K(T) \times V_{\text {suspension }}\right)$, where $V_{\text {suspension }}$ and $V_{\text {air }}$ rep- resent the total liquid volume analyzed per sample $(0.75 \mathrm{~mL}$ for the three tests) and total volume of air drawn per sample $(39888 \mathrm{~L})$, respectively.

Differential INP spectra - which as the name indicates, correspond to the differential of the cumulative spectra (Vali et al., 2015) - were used early in earlier studies (Vali, 1971; Vali and Stansbury, 1966). Spectra from these previous studies only reached a minimum of $-20^{\circ} \mathrm{C}$ due to the limitations of background artifacts in the water used at that time. Recent work by Vali (2019) and Polen et al. (2018) revisits the use of differential spectra, expanding to lower temperatures. We employ the calculation for differential INP concentrations from Vali (2019):

$k(T)=-\frac{1}{V_{\text {drop }} \times \Delta T} \times \ln \left(1-\frac{\Delta N}{N(T)}\right)$,

where $N$ is the number of unfrozen drops and $\Delta N$ is the number of freezing events observed between $T$ and $(T-\Delta T)$. Differential concentrations were divided by the maximum concentration per sample (i.e., to normalize) then smoothed using a moving average.

\subsection{Supporting meteorological and source analysis data}

Auxiliary surface meteorological observations, including but not limited to hourly mean air temperature measured $2 \mathrm{~m}$ above ground level (a.g.l.) $\left({ }^{\circ} \mathrm{C}\right)$, relative humidity measured $2 \mathrm{~m}$ a.g.l. (\%), scalar wind speed $\left(\mathrm{m} \mathrm{s}^{-1}\right)$ and direction (degrees), and incoming longwave radiation $\left(\mathrm{W} \mathrm{m}^{-2}\right)$, were acquired from MeteoSwiss (https://gate.meteoswiss.ch/ idaweb/, last access: August 2018). From the longwave measurements, in-cloud conditions were determined by calculating the sky temperature and comparing to air temperature measured at the station, as per the methodology of Herrmann et al. (2015) from a 6-year analysis of JFJ observations. There were no in situ measurements of cloud presence or extent. For the current work, each hourly measurement was categorized as out of cloud or in cloud based on such calculations and averaged to obtain daily cloud coverage percentage.

Radon $\left({ }^{222} \mathrm{Rn}\right)$ concentrations have been continuously measured at JFJ since 2009. Details on the detectors themselves and the measurements can be found in Griffiths et al. (2014). Briefly, $30 \mathrm{~min}$ radon concentrations were measured using a dual-flow-loop two-filter radon detector as described by Chambers et al. (2016). Calibrated radon concentrations were converted from activity concentration at ambient conditions to a quantity which is conserved during an air parcel's ascent: activity concentration at standard temperature and pressure $\left(0^{\circ} \mathrm{C}, 1013 \mathrm{hPa}\right)$, written as becquerels per cubic meter $\left(\mathrm{Bq} \mathrm{m}^{-3}\right)$ STP (Griffiths et al., 2014). Time periods with BLI were classified as radon concentrations $>$ $2 \mathrm{~Bq} \mathrm{~m}^{-3}$ (Griffiths et al., 2014). Particle concentrations from approximately 0.3 to $>20 \mu \mathrm{m}$ in diameter were measured with a 15-channel optical particle sizer (OPS 3300; TSI, Inc.) 
at a 1 min time resolution (Bukowiecki et al., 2016). Due to operational complications, OPS data were not collected prior to 23 February during INCAS. Air was drawn through a heated total aerosol inlet $\left(25^{\circ} \mathrm{C}\right)$ which, besides aerosol particles, enables hydrometeors with diameters $<40 \mu \mathrm{m}$ to enter and to evaporate, at wind speeds of $20 \mathrm{~m} \mathrm{~s}^{-1}$ (Weingartner et al., 1999). SDEs were determined from existing methodology using various aerosol optical properties but, specifically, the Angström exponent of the single-scattering albedo ( $\stackrel{\circ}{S S A}_{\text {SA }}$, which decreases with wavelength during SDEs (Collaud Coen et al., 2004; Bukowiecki et al., 2016). SDEs are automatically detected by the occurrence of negative $a_{\text {SSA }}$ 's that last more than $4 \mathrm{~h}$. Based on previous work, most of the SDEs do not lead to a detectable increase in the $48 \mathrm{~h}$ total suspended particulate matter concentrations at JFJ (Collaud Coen et al., 2004). Additionally, we consider these events probable SDEs but may have influences from other sources in addition.

Air mass transport analyses were conducted using the Hybrid Single-Particle Lagrangian Integrated Trajectory (HYSPLIT) model with the SplitR package for RStudio (https: //github.com/rich-iannone/SplitR, last access: August 2018) (Draxler, 1999; Draxler and Rolph, 2011; Stein et al., 2015). Reanalysis data from the National Centers for Environmental Prediction (NCEP) and National Center for Atmospheric Research (NCAR) (2.5 latitude-longitude; 6hourly; https://www.ready.noaa.gov/gbl_reanalysis.php, last access: August 2018) were used as the meteorological fields in HYSPLIT simulations. Air mass transport directionality and frontal passages were verified by NCEP-NCAR reanalyses of wind vectors and geopotential height at $600 \mathrm{mbar}$ (i.e., approximate pressure at the altitude of JFJ; https: //www.esrl.noaa.gov/psd/data/composites/day/, last access: August 2018). Trajectories were initiated at 10, 500, and $1000 \mathrm{~m}$ a.g.l. every $3 \mathrm{~h}$ daily, but only the $500 \mathrm{~m}$ trajectories are shown. Trajectories were only simulated for each northwesterly, southeasterly, SDE, and BLI case study day (i.e., Table 1). It is important to note that "northwesterly" is a contribution of north, west, and northwest winds, while "southeasterly" includes south, east, and southeast winds. SDE and BLI days were predominantly (not entirely) southeasterly.

\section{Results and discussion}

\subsection{Directional dichotomy of air masses arriving at JFJ during INCAS}

Local surface meteorology was variable at JFJ during INCAS, with air temperatures ranging from -27.5 to $-4.8^{\circ} \mathrm{C}$ (average of $-13.7^{\circ} \mathrm{C}$ ) - temperatures relevant to heterogeneous nucleation of cloud ice - and relative humidity ranging from $18 \%$ to $100 \%$ (Fig. 1a). All days contained some fraction of in-cloud conditions that varied between $12 \%$ and $100 \%$, on average. Due to the topography surrounding JFJ, predominant wind directions were northwest followed by southeast, with the fastest winds recorded originating from the southeast (Fig. 2). Such conditions are typical for JFJ during the winter (Stopelli et al., 2015; Collaud Coen et al., 2011). Out of the entire study, several days were classified as northwesterly (5 days) or southeasterly (2 days) conditions when a combination of aerosol, cloud rime, and snow samples were collected (i.e., a full $24 \mathrm{~h}$ of northwesterly or a full $24 \mathrm{~h}$ of southeasterly winds during snowfall; Table 1), which are herein focused on as the case study days (indicated by the blue and red in Fig. 1b, respectively). These days were also deemed days with storm conditions since clouds and snow were both present at JFJ. There were 4 days that maintained predominantly southerly wind directions as indicated in green in Fig. $1 \mathrm{~b}$ and Table 1 and were characterized as days influenced by SDEs or BLI as discussed herein. Rime and snow were only collected on one of these days, while remaining SDE or BLI cases had only aerosol collected. Aside from 22 February (missing data), the remaining days in the study were characterized as FT and did not exhibit influences from warm-temperature INPs (see Sect. 3.2 and 3.3).

Most southeasterly case days (and 6 March) apart from the SDE days experienced longer residence times in what was likely the boundary layer (i.e., $1000 \mathrm{~m}$ or less) compared to northwesterly cases, which is supported by radon data (Fig. 1c). Griffiths et al. (2014) determined that radon concentrations $>2 \mathrm{~Bq} \mathrm{~m}^{-3}$ signify BLI, which in the current work was clearly observed on 23 February, 27 February, 28 February, 6 March, and 11 March case days, indicating samples collected on these days were likely influenced by continental boundary layer sources. Relatively low radon concentrations were observed on the remaining case study days, indicating these samples were predominantly affected by free-tropospheric (FT) air and, thus, lower aerosol concentrations and/or more distant, including marine, sources. Although OPS data were missing until 23 February, source information can be gleaned from the available data. For example, 23 February had episodic high concentrations of particles (maximum of $9.6 \mathrm{~cm}^{-3}$ ) towards the beginning of the day coincident with the largest spike in radon, with a steady decrease as time transpired, indicating the boundary layer was an ample source of $>0.3 \mu \mathrm{m}$ particles. A similar episode with the OPS and radon concentrations was observed 2728 February, where the highest concentrations of each were observed during the entire study period. Selected days were subject to diurnal winds (not shown), such as 6 March, where boundary layer air reached JFJ and a midday maximum in OPS particle concentrations was observed, indicating lower elevations were the dominant source of aerosol. Although, diurnal variations in aerosol from local sources have been shown to not be common in the winter at JFJ (Baltensperger et al., 1997). In contrast, 11 March was exposed to boundary layer air based on radon observations, but particle concentrations were low (average of $0.2 \mathrm{~cm}^{-3}$ compared to a study average of $3.0 \mathrm{~cm}^{-3}$ ), signifying that although BLI occurred 
Table 1. Dates and times for cloud rime, snow, and aerosol samples collected during the 2018 winter INCAS study at Jungfraujoch. Also shown are the dominant air mass sources (free troposphere or FT or boundary layer intrusion of BLI) for each day based on radon data. Samples labeled as NW and SE under "Direction" are the northwest and southeast case studies, respectively. Samples labeled as S under "Direction" represent predominantly southerly days that were classified as Saharan dust events (SDEs) or BLI days.

\begin{tabular}{|c|c|c|c|c|c|c|c|c|c|c|c|c|}
\hline \multirow[t]{2}{*}{ Date } & \multirow[t]{2}{*}{ Direction } & \multirow[t]{2}{*}{ Air mass } & \multicolumn{3}{|c|}{ Cloud rime } & \multicolumn{3}{|c|}{ Snow } & \multicolumn{4}{|c|}{ Aerosol } \\
\hline & & & Sample & $\begin{array}{l}\text { Start } \\
\text { (UTC) }\end{array}$ & $\begin{array}{l}\text { Duration } \\
\text { (hh:mm) }\end{array}$ & Sample & $\begin{array}{l}\text { Start } \\
\text { (UTC) }\end{array}$ & $\begin{array}{l}\text { Duration } \\
\text { (hh:mm) }\end{array}$ & Sample & $\begin{array}{l}\text { Start } \\
\text { (UTC) }\end{array}$ & $\begin{array}{l}\text { Duration } \\
\text { (hh:mm) }\end{array}$ & Stages \\
\hline $15 \mathrm{Feb}$ & NW & FT & $\begin{array}{l}\text { Rime1 } \\
\text { Rime2 } \\
\text { Rime3 } \\
\text { Rime4 } \\
\text { Rime5 }\end{array}$ & $\begin{array}{l}06: 30 \\
09: 37 \\
11: 50 \\
15: 45 \\
19: 20\end{array}$ & $\begin{array}{l}03: 07 \\
02: 13 \\
03: 55 \\
03: 35 \\
13: 55\end{array}$ & $\begin{array}{l}\text { Snow1 } \\
\text { Snow2 } \\
\text { Snow3 } \\
\text { Snow4 } \\
\text { Snow5 }\end{array}$ & $\begin{array}{l}07: 15 \\
08: 40 \\
10: 10 \\
12: 45 \\
15: 20\end{array}$ & $\begin{array}{l}01: 15 \\
01: 30 \\
01: 35 \\
02: 30 \\
04: 00\end{array}$ & $\begin{array}{l}\text { DRUM1 } \\
\text { DRUM2 }\end{array}$ & $\begin{array}{l}10: 00 \\
22: 00\end{array}$ & $\begin{array}{l}12: 00 \\
24: 00\end{array}$ & $\begin{array}{l}\text { A, B, C, D } \\
\text { A, B, C, D }\end{array}$ \\
\hline $16 \mathrm{Feb}$ & NW & FT & $\begin{array}{l}\text { Rime6 } \\
\text { Rime7 }\end{array}$ & $\begin{array}{l}07: 15 \\
09: 29\end{array}$ & $\begin{array}{l}02: 10 \\
02: 41\end{array}$ & $\begin{array}{l}\text { Snow6 } \\
\text { Snow7 } \\
\text { Snow8 }\end{array}$ & $\begin{array}{l}07: 15 \\
09: 23 \\
14: 00\end{array}$ & $\begin{array}{l}02: 02 \\
02: 37 \\
17: 50\end{array}$ & DRUM3 & $22: 00$ & $24: 00$ & $\mathrm{~A}, \mathrm{~B}, \mathrm{C}, \mathrm{D}$ \\
\hline $17 \mathrm{Feb}$ & None & FT & $\begin{array}{l}\text { Rime8 } \\
\text { Rime9 } \\
\text { Rime10 } \\
\text { Rime11 }\end{array}$ & $\begin{array}{l}12: 08 \\
13: 24 \\
15: 47 \\
18: 59\end{array}$ & $\begin{array}{l}01: 16 \\
02: 23 \\
03: 12 \\
06: 48\end{array}$ & $\begin{array}{l}\text { Snow9 } \\
\text { Snow10 } \\
\text { Snow11 } \\
\text { Snow12 } \\
\text { Snow13 } \\
\text { Snow14 } \\
\text { Snow15 } \\
\text { Snow16 }\end{array}$ & $\begin{array}{l}07: 50 \\
10: 16 \\
11: 35 \\
12: 20 \\
13: 42 \\
14: 45 \\
15: 54 \\
18: 52\end{array}$ & $\begin{array}{l}02: 23 \\
01: 10 \\
00: 33 \\
01: 04 \\
01: 00 \\
00: 55 \\
02: 54 \\
05: 50\end{array}$ & DRUM4 & $22: 00$ & $24: 00$ & $\mathrm{~A}, \mathrm{~B}, \mathrm{C}, \mathrm{D}$ \\
\hline $18 \mathrm{Feb}$ & None & FT & Rime12 & $00: 47$ & $08: 22$ & & None & & DRUM5 & $22: 00$ & $24: 00$ & $\mathrm{~A}, \mathrm{~B}, \mathrm{C}$ \\
\hline 19 Feb & NW & FT & Rime13 & $21: 00$ & $10: 50$ & Snow17 & 21:00 & $08: 50$ & DRUM6 & $22: 00$ & $24: 00$ & $\mathrm{~A}, \mathrm{~B}, \mathrm{C}$ \\
\hline $20 \mathrm{Feb}$ & NW & FT & $\begin{array}{l}\text { Rime14 } \\
\text { Rime15 }\end{array}$ & $\begin{array}{l}05: 50 \\
12: 08\end{array}$ & $\begin{array}{l}04: 14 \\
02: 17\end{array}$ & $\begin{array}{l}\text { Snow18 } \\
\text { Snow19 }\end{array}$ & $\begin{array}{l}05: 50 \\
12: 08\end{array}$ & $\begin{array}{l}04: 14 \\
02: 14\end{array}$ & DRUM7 & $22: 00$ & $24: 00$ & $\mathrm{~A}, \mathrm{~B}, \mathrm{C}$ \\
\hline $21 \mathrm{Feb}$ & None & FT & & None & & & None & & DRUM8 & $22: 00$ & $24: 00$ & $\mathrm{~A}, \mathrm{~B}, \mathrm{C}, \mathrm{D}$ \\
\hline $22 \mathrm{Feb}$ & None & BLI & & None & & & None & & DRUM9 & $22: 00$ & $24: 00$ & $\mathrm{~A}, \mathrm{~B}, \mathrm{C}, \mathrm{D}$ \\
\hline $23 \mathrm{Feb}$ & SE & BLI & Rime16 & 20:00 & $14: 30$ & $\begin{array}{l}\text { Snow20 } \\
\text { Snow21 } \\
\text { Snow22 } \\
\text { Snow23 }\end{array}$ & $\begin{array}{l}07: 49 \\
10: 55 \\
14: 40 \\
20: 00\end{array}$ & $\begin{array}{l}02: 51 \\
03: 35 \\
02: 42 \\
12: 11\end{array}$ & DRUM10 & $22: 00$ & $24: 00$ & A, B, C, D \\
\hline $24 \mathrm{Feb}$ & $\mathrm{S}$ & FT, SDE & & None & & & None & & DRUM11 & $22: 00$ & $24: 00$ & $\mathrm{~A}, \mathrm{~B}, \mathrm{C}$ \\
\hline $25 \mathrm{Feb}$ & None & FT & & None & & & None & & DRUM12 & $22: 00$ & $24: 00$ & A, B \\
\hline $26 \mathrm{Feb}$ & None & FT & & None & & & None & & DRUM13 & $22: 00$ & $24: 00$ & $\mathrm{~A}, \mathrm{~B}, \mathrm{C}$ \\
\hline $27 \mathrm{Feb}$ & S & BLI & & None & & & None & & DRUM14 & $22: 00$ & $24: 00$ & $\mathrm{~A}, \mathrm{~B}, \mathrm{C}$ \\
\hline $28 \mathrm{Feb}$ & $\mathrm{S}$ & BLI & & None & & & None & & DRUM15 & $22: 00$ & $24: 00$ & $\mathrm{~A}, \mathrm{~B}, \mathrm{C}$ \\
\hline $1 \mathrm{Mar}$ & None & BLI & & None & & & None & & DRUM16 & $22: 00$ & $24: 00$ & $\mathrm{~A}, \mathrm{~B}, \mathrm{C}$ \\
\hline 2 Mar & None & FT & & None & & & None & & DRUM17 & $22: 00$ & $24: 00$ & $\mathrm{~A}, \mathrm{~B}, \mathrm{C}$ \\
\hline $3 \mathrm{Mar}$ & None & FT & & None & & & None & & DRUM18 & $22: 00$ & $24: 00$ & $\mathrm{~A}, \mathrm{~B}, \mathrm{C}$ \\
\hline 4 Mar & None & FT & & None & & & None & & DRUM19 & 22:00 & 24:00 & $\mathrm{A}, \mathrm{B}, \mathrm{C}$ \\
\hline 5 Mar & None & FT & Rime17 & $16: 43$ & $15: 32$ & Snow24 & $21: 52$ & 08:16 & DRUM20 & $22: 00$ & $24: 00$ & $\mathrm{~A}, \mathrm{~B}, \mathrm{C}$ \\
\hline $6 \mathrm{Mar}$ & NW & BLI & $\begin{array}{l}\text { Rime18 } \\
\text { Rime19 } \\
\text { Rime20 } \\
\text { Rime21 } \\
\text { Rime22 }\end{array}$ & $\begin{array}{l}06: 15 \\
09: 18 \\
15: 00 \\
17: 08 \\
22: 38\end{array}$ & $\begin{array}{l}03: 03 \\
05: 42 \\
02: 08 \\
04: 41 \\
21: 40\end{array}$ & $\begin{array}{l}\text { Snow25 } \\
\text { Snow26 } \\
\text { Snow27 } \\
\text { Snow28 } \\
\text { Snow29 }\end{array}$ & $\begin{array}{l}06: 15 \\
09: 14 \\
14: 54 \\
17: 26 \\
22: 38\end{array}$ & $\begin{array}{l}02: 50 \\
05: 26 \\
01: 56 \\
04: 04 \\
07: 35\end{array}$ & DRUM21 & $22: 00$ & $24: 00$ & $\mathrm{~A}, \mathrm{~B}, \mathrm{C}$ \\
\hline 7 Mar & None & BLI & $\begin{array}{l}\text { Rime23 } \\
\text { Rime24 } \\
\text { Rime25 } \\
\text { Rime26 }\end{array}$ & $\begin{array}{l}06: 19 \\
10: 17 \\
15: 57 \\
22: 28\end{array}$ & $\begin{array}{l}03: 58 \\
05: 40 \\
08: 31 \\
06: 34\end{array}$ & $\begin{array}{l}\text { Snow30 } \\
\text { Snow31 } \\
\text { Snow32 } \\
\text { Snow33 } \\
\text { Snow34 }\end{array}$ & $\begin{array}{l}06: 19 \\
07: 50 \\
12: 49 \\
16: 00 \\
22: 28\end{array}$ & $\begin{array}{l}01: 19 \\
02: 00 \\
02: 59 \\
05: 19 \\
06: 27\end{array}$ & DRUM22 & $22: 00$ & $24: 00$ & $\mathrm{~A}, \mathrm{~B}, \mathrm{C}$ \\
\hline
\end{tabular}


Table 1. Continued.

\begin{tabular}{|c|c|c|c|c|c|c|c|c|c|c|c|c|}
\hline \multirow[t]{2}{*}{ Date } & \multirow[t]{2}{*}{ Direction } & \multirow[t]{2}{*}{ Air mass } & \multicolumn{3}{|c|}{ Cloud rime } & \multicolumn{3}{|c|}{ Snow } & \multicolumn{4}{|c|}{ Aerosol } \\
\hline & & & Sample & $\begin{array}{l}\text { Start } \\
\text { (UTC) }\end{array}$ & $\begin{array}{l}\text { Duration } \\
\text { (hh:mm) }\end{array}$ & Sample & $\begin{array}{l}\text { Start } \\
\text { (UTC) }\end{array}$ & $\begin{array}{l}\text { Duration } \\
\text { (hh:mm) }\end{array}$ & Sample & $\begin{array}{l}\text { Start } \\
\text { (UTC) }\end{array}$ & $\begin{array}{l}\text { Duration } \\
\text { (hh:mm) }\end{array}$ & Stages \\
\hline 8 Mar & None & FT & & None & & & None & & DRUM23 & $22: 00$ & $24: 00$ & $\mathrm{~A}, \mathrm{~B}, \mathrm{C}$ \\
\hline 9 Mar & None & FT & & None & & & None & & DRUM24 & $22: 00$ & $24: 00$ & $\mathrm{~A}, \mathrm{~B}, \mathrm{C}$ \\
\hline $10 \mathrm{Mar}$ & $S$ & FT, SDE & Rime27 & $11: 00$ & $21: 46$ & $\begin{array}{l}\text { Snow35 } \\
\text { Snow36 }\end{array}$ & $\begin{array}{l}06: 00 \\
10: 10\end{array}$ & $\begin{array}{l}04: 00 \\
01: 56\end{array}$ & DRUM25 & $22: 00$ & $24: 00$ & A, B, C \\
\hline $11 \mathrm{Mar}$ & SE & BLI & $\begin{array}{l}\text { Rime28 } \\
\text { Rime29 } \\
\text { Rime30 }\end{array}$ & $\begin{array}{l}06: 46 \\
09: 56 \\
13: 45\end{array}$ & $\begin{array}{l}02: 59 \\
03: 49 \\
04: 48\end{array}$ & $\begin{array}{l}\text { Snow37 } \\
\text { Snow38 } \\
\text { Snow39 }\end{array}$ & $\begin{array}{l}05: 48 \\
09: 54 \\
13: 48\end{array}$ & $\begin{array}{l}04: 03 \\
03: 51 \\
02: 28\end{array}$ & None & & & \\
\hline
\end{tabular}
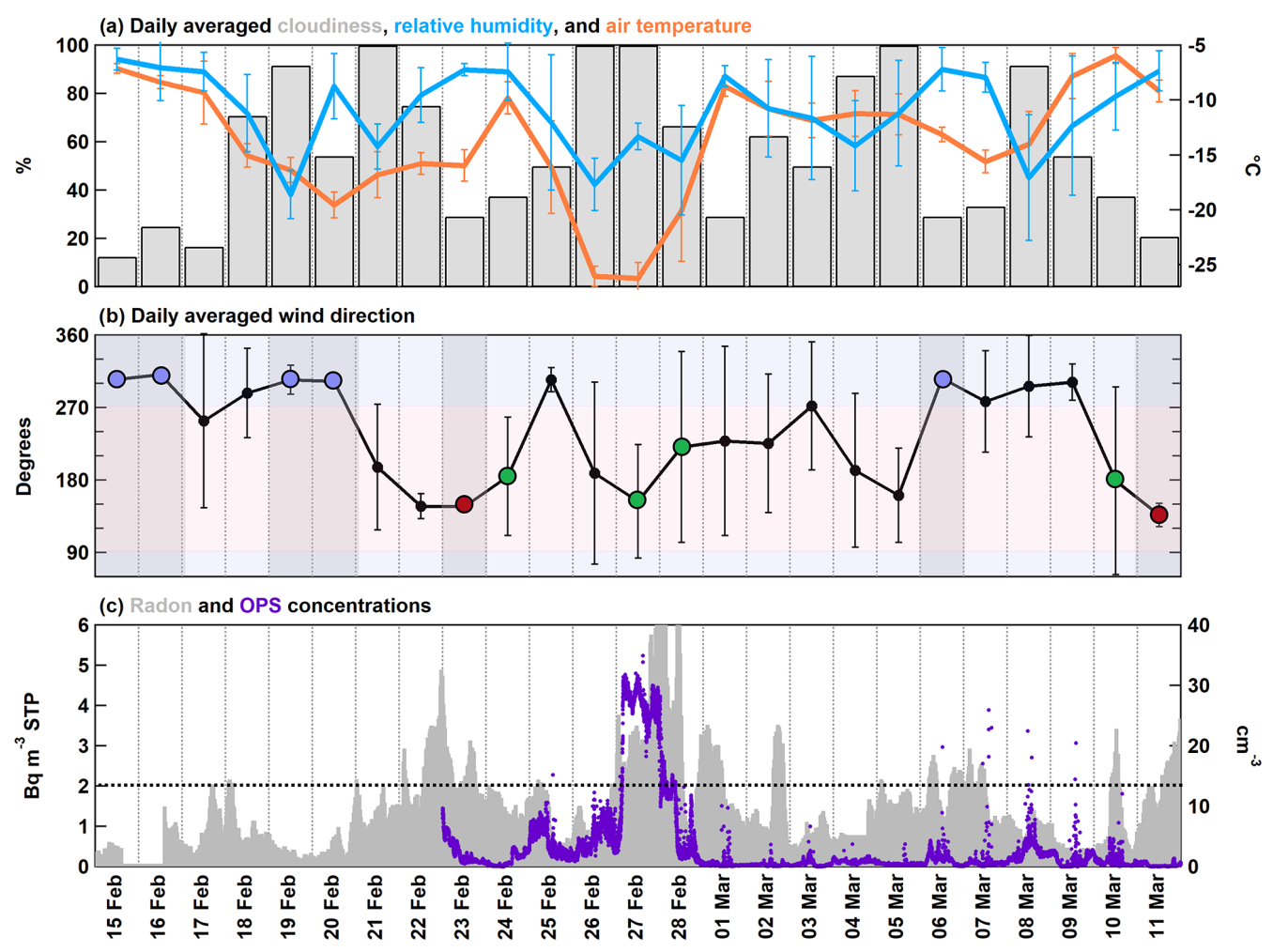

Figure 1. Daily averaged meteorological data at JFJ from INCAS, including (a) percentage of cloudiness in the vertical profile over JFJ as per the estimation by Herrmann et al. (2015), station relative humidity $(\%)$, and station air temperature $\left({ }^{\circ} \mathrm{C}\right)$ and (b) station wind direction. The background of (b) is shaded horizontally by north (light blue) or south (light red) directions. Additionally, days with combined aerosol, cloud rime, and snow collections are vertically shaded grey. Blue and red markers for wind direction represent case study storm days that were entirely northwesterly or southeasterly, respectively. Green markers represent predominantly southerly days that were classified as Saharan dust events (SDEs) or heavy boundary layer influence days. (c) Time series of radon $\left({ }^{222} \mathrm{Rn}\right)$ corrected for standard temperature and pressure and OPS particle concentrations. The black dashed line indicates a threshold of $2 \mathrm{~Bq} \mathrm{~m}^{-3}$ whereby boundary layer intrusion likely occurred at JFJ. OPS data were missing prior to 23 February. Error bars represent standard deviation.

at JFJ, it was not a substantial source of aerosol. These relationships corroborate the ice nucleation observations, as discussed in detail below.

Extending past local conditions, air mass transport $10 \mathrm{~d}$ back in time prior to reaching JFJ on case study days was, as expected, dissimilar between northwesterly (Fig. 3) and southeasterly, SDE, or BLI (Fig. 4) conditions. The main dis- tinctions between northwesterly and southeasterly, SDE, or BLI days are that (1) northwesterly days originated from farther west, with some days reaching back to North America, while air masses on southeasterly, SDE, or BLI days predominantly hovered over land and oceanic sources closer to Europe; (2) southeasterly, SDE, or BLI air masses traveled closer to the surface relative to northwesterly days, while 


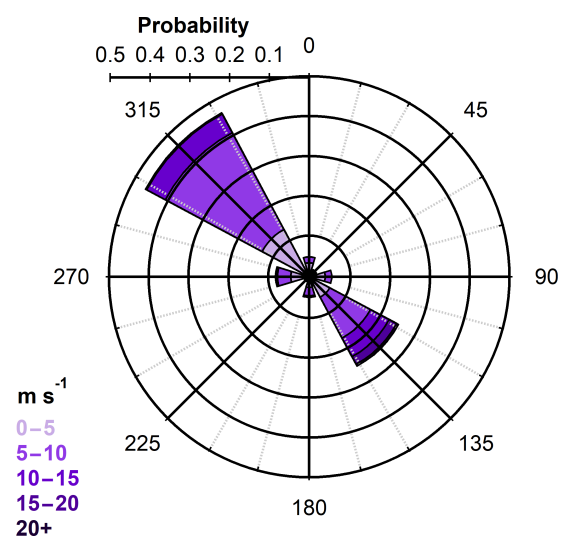

Figure 2. Rose plot for wind data during INCAS. Values correspond to wind direction binned by $45^{\circ}$ and wind speeds binned by $5 \mathrm{~m} \mathrm{~s}^{-1}$. The probability for wind speed to fall within these bins is plotted.

northwesterly air masses were typically transported from higher altitudes (i.e., more FT exposure); and (3) aside from 6 March (which is discussed in more detail in the following section), northwesterly air masses did not travel over the Mediterranean and northern Africa, whereas the southeasterly, SDE, or BLI air masses above JFJ arrived from over such regions within less than $2 \mathrm{~d}$ before arriving to JFJ. One obvious inconsistency is that the air mass trajectories on 24 February do not indicate transport occurred from northern Africa even though this day was characterized as an SDE. Collaud Coen et al. (2004) reported that, in $71 \%$ of all cases they evaluated at JFJ, $10 \mathrm{~d}$ back-trajectories were able to reveal the source of Saharan dust and that back trajectories cannot always explain SDEs. Boose et al. (2016) reported similar transport pathways for JFJ during multiple consecutive winters and concluded that marine and Saharan dust served as dominant sources of INPs at $-33^{\circ} \mathrm{C}$. Reche et al. (2018) also reported similar pathways and sources for bacteria and viruses but during the summer in southern Spain. These disparate sources and transport pathways of air support the variability in the ice nucleation observations as discussed in more detail in the following section.

\subsection{Variability in INP spectra based on air mass source}

Out of the 25 aerosol, 30 rime, and 39 snow samples collected, 7 aerosol, 19 rime, and 23 snow samples were collected on northwesterly or southeasterly storm case study days, while 4 aerosol, 1 rime, and 2 snow samples were collected on SDE or BLI days (Table 1). Most mixed wind direction days were excluded, as sources from both directions would contribute to the daily aerosol sample. Figure 5 shows the cumulative $(K(T))$ and differential $(k(T))$ INP concentrations from aerosol, snow, and rime samples on the case days. The use of $k(T)$ demonstrates the presence of 1-2 INP populations by having a mode in the warm regime (i.e., warm mode or likely biological) and enables us to intercompare be- tween the different types of samples from different air mass sources at JFJ.

In addition to containing higher concentrations of warmtemperature INPs, most southeasterly and SDE/BLI samples contained a clear mode in the warm-temperature regime compared to northwesterly samples which typically did not contain such a mode in the $k(T)$ spectra. This warm mode, or "bump" at temperatures above approximately $-15^{\circ} \mathrm{C}$, has been observed in a wide range of previous immersion mode ice nucleation studies including but not limited to some of the earliest studies of total aerosol (Vali, 1971), residuals found in hail (Vali and Stansbury, 1966), sea spray aerosol (McCluskey et al., 2017; DeMott et al., 2016), soil samples (Hill et al., 2016), agricultural harvesting emissions (Suski et al., 2018), and in recent reviews of aerosol (Kanji et al., 2017; DeMott et al., 2018) and precipitation (Petters and Wright, 2015) samples. Most previous studies that show spectra with the warm mode typically (1) report a wide range of freezing temperatures such that it can be observed relative to the steady increase in INPs at colder temperatures or (2) are of samples that include a mixture of biological and mineral or other less efficient INP sources. For example, several previous studies report INP concentrations down to only $-15^{\circ} \mathrm{C}$ (e.g., Conen and Yakutin, 2018; Hara et al., 2016; Kieft, 1988; Schnell and Vali, 1976; Vali et al., 1976; Wex et al., 2015), namely because the goal was to target efficient, warmtemperature biological INPs. However, the warm mode may not be evident in such studies, given it cannot be visualized next to the drastic increase in INPs with temperatures below $-15^{\circ} \mathrm{C}$. In contrast, studies conducting INP measurements on known mineral dust samples also are not able to observe the warm mode (e.g., Price et al., 2018; Atkinson et al., 2013; Murray et al., 2012). Recently, Beydoun et al. (2017) demonstrate that mixtures of biological and mineral particles can be resolved through careful analysis based on their controlled experimentation using known Snowmax ${ }^{\circledR}$ and illite mineral mixtures. Together, it is apparent that a mixed biological and mineral (or less efficient biological INPs) sample is needed to assess the modal behavior in the INP spectra. However, we note the tentative nature of characterizing these modes based on the previous body of literature and on the fact that more controlled, quantitative experiments of mixed biological-mineral INPs are needed in the future.

Only the largest size range of the aerosol is shown because the remaining size ranges (i.e., $<2.96 \mu \mathrm{m}$ ) were not distinct with respect to wind direction. The fact that size, alone, exhibited directionally dependent results and that such dependencies were only observed in the coarse-mode aerosol indicate that (1) the sources were indeed different between northwesterly, southeasterly, and SDE/BLI transport - supporting the air mass source analyses - and (2) the coarsemode aerosols were likely from a regional source as opposed to long-range transported thousands of kilometers. This is because gravitational settling typically renders transport of coarse particles inefficient especially within the boundary 

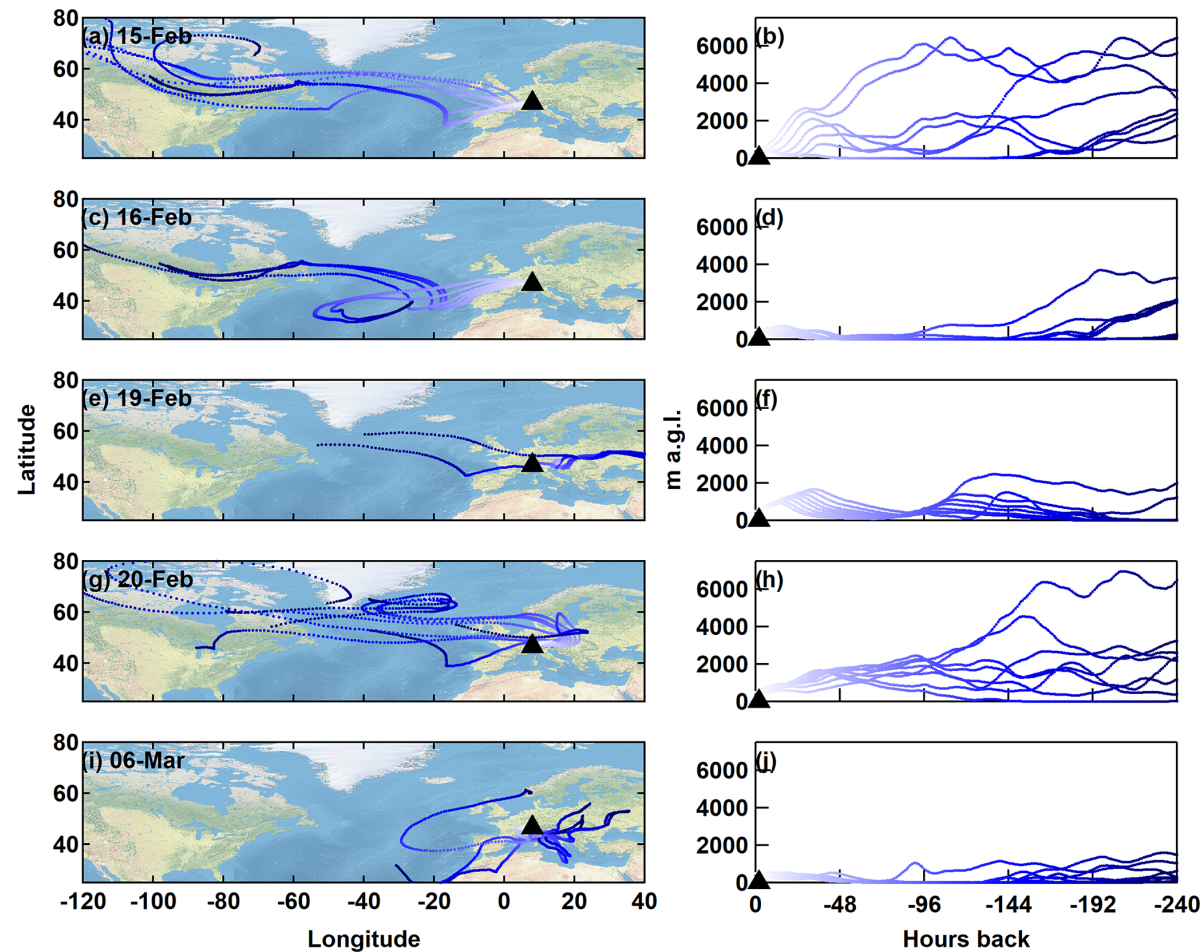

Figure 3. The $10 \mathrm{~d}$ air mass backward trajectories initiated every $3 \mathrm{~h}$ during sample collection for northwesterly case days ending at $500 \mathrm{~m}$ above ground level (a.g.l.). Trajectories are plotted by latitude-longitude (left) and altitude-time (right) profiles for 15 February (a, b), 16 February $(\mathbf{c}, \mathbf{d}), 19$ February $(\mathbf{e}, \mathbf{f}), 20$ February $(\mathbf{g}, \mathbf{h})$, and 6 March $(\mathbf{i}, \mathbf{j})$. Darker shades of blue represent trajectory points farther back in time.

layer (Creamean et al., 2018a; Jaenicke, 1980). Previous work by Collaud Coen et al. (2018) concludes that the local boundary layer infrequently influences JFJ in the winter, supporting the current work (i.e., more FT days (17 of 25 d); Table 1).

Generally, INPs from southeasterly and SDE/BLI days were higher in concentration and more efficient (i.e., were warm-temperature INPs that facilitated ice formation > $-15^{\circ} \mathrm{C}$ ) than northwesterly samples. Our results are parallel to those by Stopelli et al. (2016), who also observed higher $K(T)$ in snow samples collected during southerly conditions at JFJ from December 2012 to October 2014 (Fig. 6a). However, $K(T)$ values reported here were generally higher than those reported by Stopelli et al. (2016), especially for the northwesterly samples. Unlike Stopelli et al. (2016), there was no clear correlation between $K(T)$ with air temperature and wind speed in the current work (not shown).

Onset freezing temperatures (i.e., the highest temperature in which the first drop in each sample froze) were typically higher for southeast, SDE, or BLI samples as compared to the northwest (Fig. 6b), indicating influences from sources that produce warm-temperature INPs on these days. The temperatures in which $10 \%\left(T_{10}\right)$ and $50 \%\left(T_{50}\right)$ of the samples froze were also typically higher for the southeast, SDE, or BLI as compared to the northwest samples, especially for the aerosol samples, indicating higher concentrations of more efficient warm-temperature INPs.

Regarding the snow, it is possible that surface processes generate airborne ice particles, which contribute to a snow sample collected at a mountain station (Beck et al., 2018). However, snow that is resuspended during a snowfall event largely consists of the most recently fallen snow crystals covering wind-exposed surfaces. These particles are unlikely to be different from concurrently falling snow. Hence, their contribution will not change INP abundance or spectral properties of the collected sample. Another matter is hoar frost crystals, which can be very abundant in terms of number but because of their small size (i.e., $<100 \mu \mathrm{m}$; Lloyd et al., 2015) can only make a minor contribution to the mass of solid precipitation depositing in a tin placed horizontally on a mountain crest. The majority of small crystals will follow the streamlines of air passing over the crest. All that an increased influence of hoar frost particles would do to our observations is to decrease measured differences between snow and rime samples, because additions of hoar frost, a form of rime, would render the collected snow sample a bit more similar to rime. 

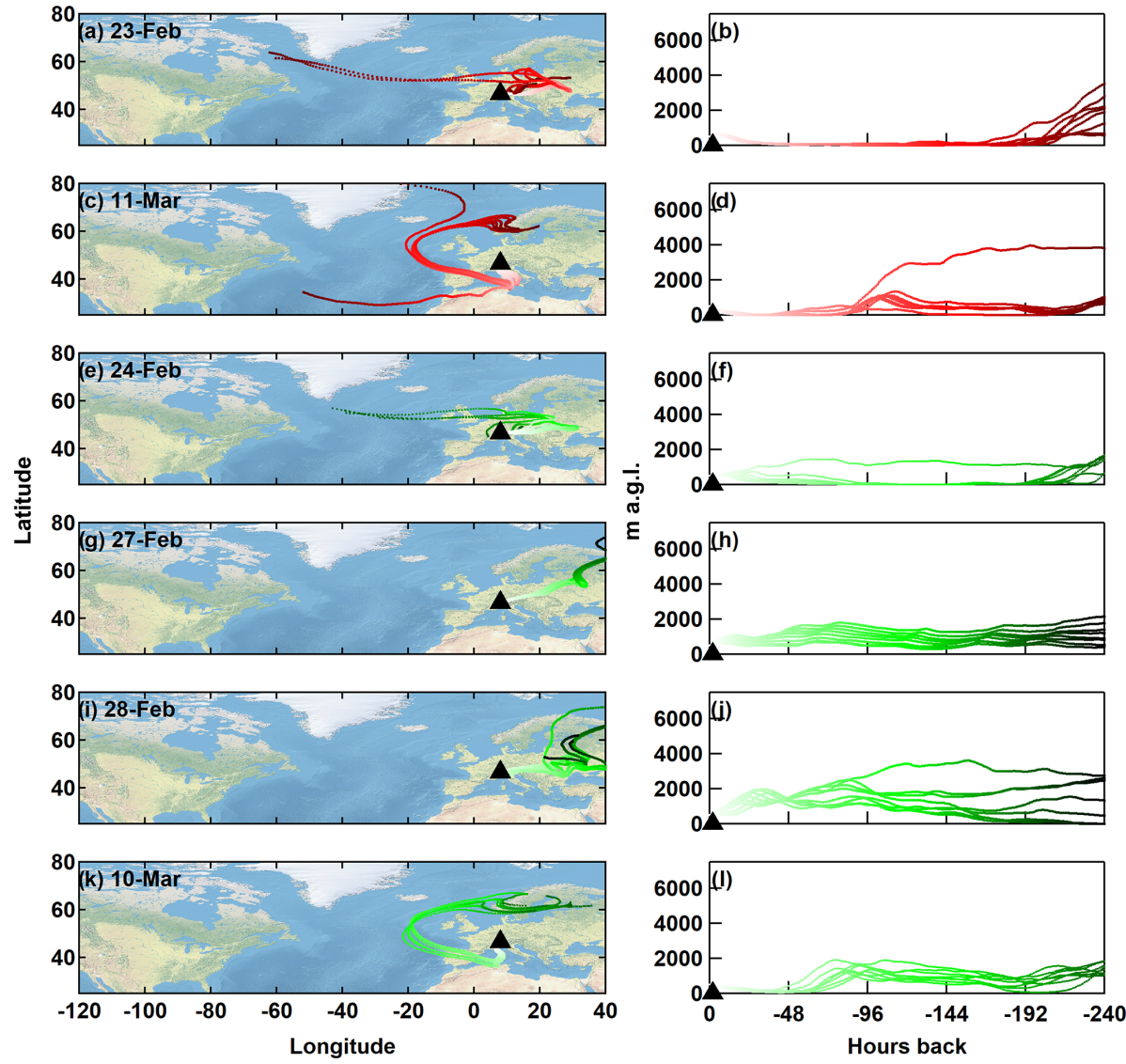

Figure 4. Same as Fig. 3 but for southeasterly (23 February and 11 March), SDE (24 February and 10 March), and BLI (27 and 28 February) case days.

\subsection{Potential components of INP populations at JFJ}

Taking the spectral characteristics in the context of air mass direction and transport can help elucidate the possible sources of INPs at JFJ during INCAS. The quantitative evaluation of the warm mode, or, likely, the relative contribution of warm-temperature biological INPs, is calculated and shown in Fig. 6e-g. Additionally, normalizing such spectra affords a qualitative comparison of spectra signatures between aerosols and residuals found in cloud rime and snow. We offer some possible explanations for the observed variability between the samples. Naturally, the boundary layer more frequently than not contains higher concentrations of warm-temperature INPs - and INPs in general - as compared to the free troposphere given the proximity to the sources (e.g., forests, agriculture, vegetation, and the oceans) (Burrows et al., 2013; Despres et al., 2012; Fröhlich-Nowoisky et al., 2016; Wilson et al., 2015; Burrows et al., 2009a, b; Fröhlich-Nowoisky et al., 2012; Suski et al., 2018). Although, microorganisms and nanoscale biological fragments are episodically lofted into the free troposphere with mineral dust and transported thousands of kilometers (Creamean et al., 2013; Kellogg and Griffin, 2006).
Air arriving at JFJ on 15 and 16 February originated from the farthest away and was not heavily exposed to boundary layer air, as evidenced by the air mass trajectory analysis (Fig. 3) and radon (Fig. 1c), indicating long-range transport in the free troposphere. This could explain why the warm mode (and higher $T_{10}$ and $T_{50}$ ) was observed for the rime and snow, but not the aerosol - the aerosol had sufficient time to nucleate ice during free-tropospheric transport and especially the warm-temperature INPs that would likely become depleted in cloud first (Stopelli et al., 2015), assuming the clouds formed along the air mass transport pathways. Cloud fraction was relatively low $(12.5 \%$ to $25 \%)$, but air temperatures were relatively high $\left(-8.4\right.$ to $\left.-7.1^{\circ} \mathrm{C}\right)$, suggesting conditions were amenable for long-range transported warm-temperature INPs to nucleate cloud ice. However, from the available data, we cannot determine with certainty if the local conditions were the same as those when nucleation initially occurred. For 19 and 20 February, air temperature was cold $\left(-16.4\right.$ and $-19.6^{\circ} \mathrm{C}$, respectively), cloud fraction was high (92\% and $54 \%$, respectively), and not all samples contained a warm mode. One possible explanation is that any warm-temperature INPs that were present in the clouds had already snowed out prior to reaching the 
(a) Cloud rime

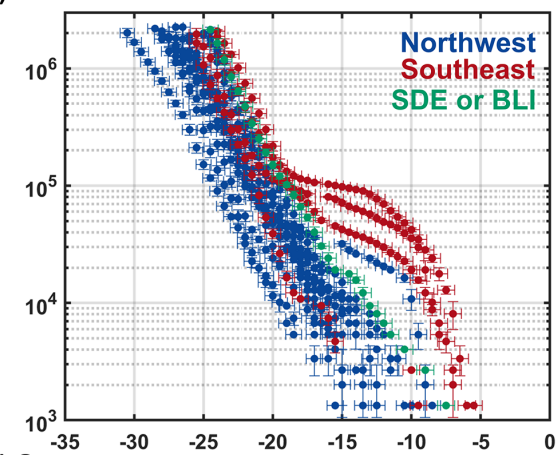

(b) Snow

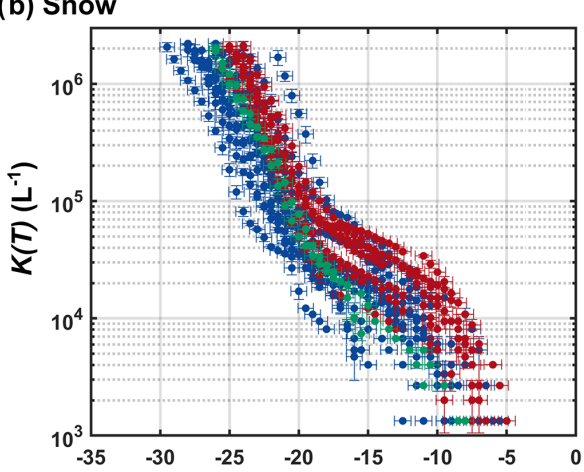

(c) Aerosol $(2.96->12 \mu \mathrm{m})$

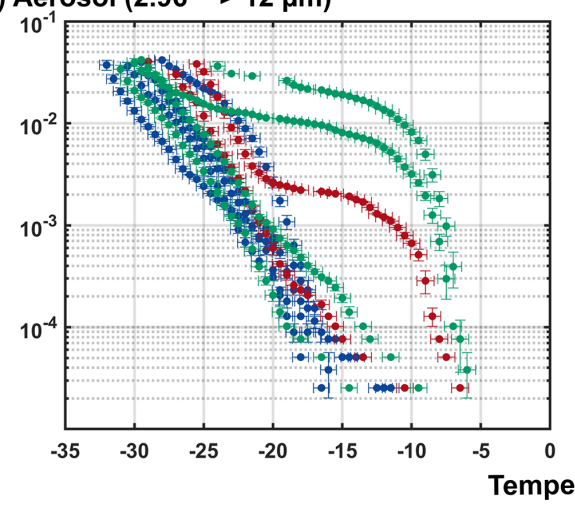

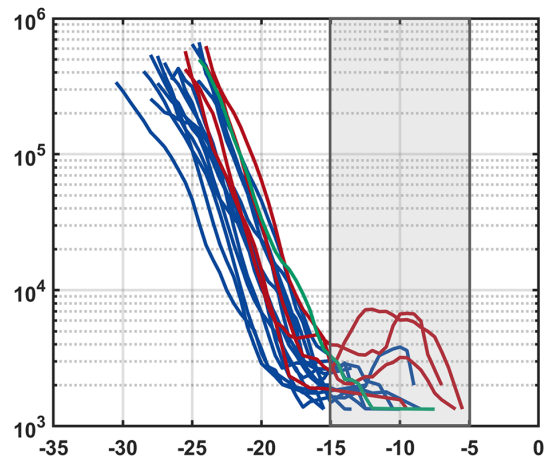
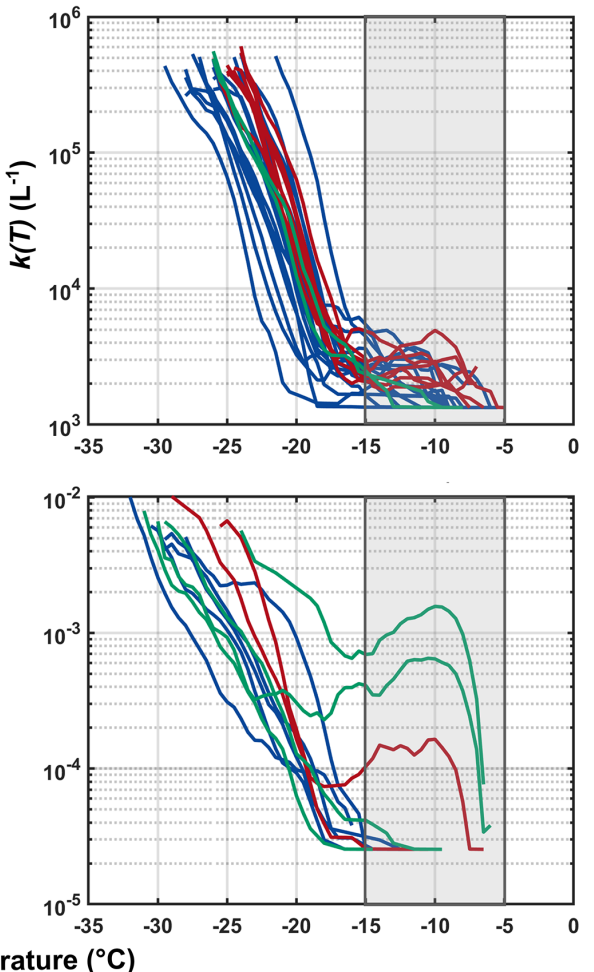

Figure 5. Cumulative INP spectra $(K(T)$, on left) and differential INP spectra $(k(T)$, on right) for the same samples of (a) cloud rime, (b) snow, and (c) aerosol for the size range 2.96-> $12 \mu \mathrm{m}$ in diameter. Spectra shown are for samples from the northwest (blue) and southeast (red) case study dates, in addition to SDE and boundary layer intrusion (BLI) case days (green). Multiple cloud rime and snow samples were collected while one aerosol sample from each size range was collected on northwest and southeast case study days (see Table 1). The warm-mode region is indicated by the dark grey shading in the $k(T)$ spectra. Note the axes are not all the same ranges.

sampling location, as observed by Stopelli et al. (2015) at JFJ. Although, given the low radon concentrations and erratic transport pathways, it is possible such air masses did not contain a relatively large concentration of warm-temperature INPs due to deficient exchange with the boundary layer. It was not until the southeasterly cases that the aerosol samples exhibited a warm mode. Specifically, on 23 February local winds shifted to southeasterly $\left(147^{\circ}\right.$ on average) and air masses arrived from over the eastern Alps, eastern Europe, Scandinavia, and earlier on in time the Atlantic Ocean. Thus, these samples were predominantly influenced by the continental (mostly over remote regions) and marine boundary layers, where sources of warm-temperature INPs are more abundant (Fröhlich-Nowoisky et al., 2016).

The northwesterly case of 6 March is somewhat interesting in that the local wind direction was clearly from the northwest, but air mass source analyses show brief transport in the boundary layer (radon) from the south, when looking farther back in time, traveling over the Mediterranean and North Africa. The aerosol sample had a high onset temperature for INPs relative to other northwest samples (Fig. 6b) and snow samples exhibited a warm mode (Fig. 6g). It is the only one of the northwesterly case samples that encountered boundary layer exposure according to the radon observations. Com- 


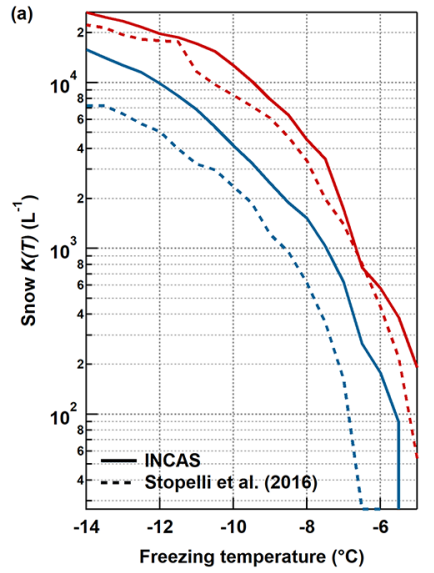

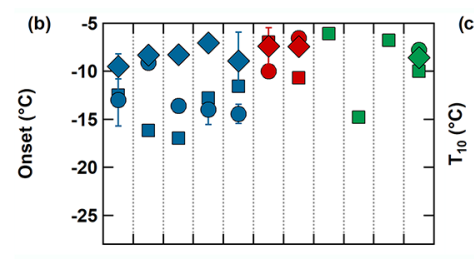

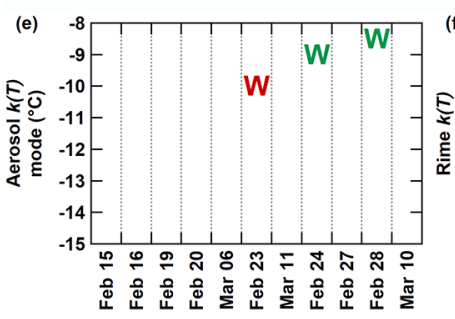

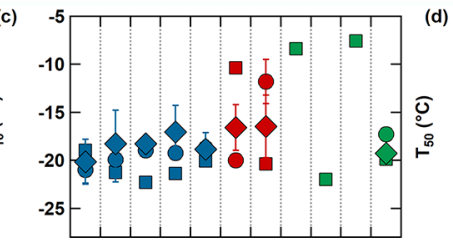

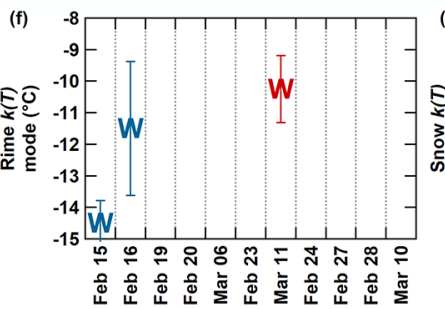

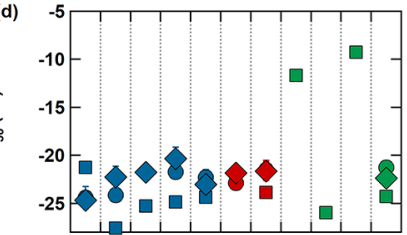

(g)

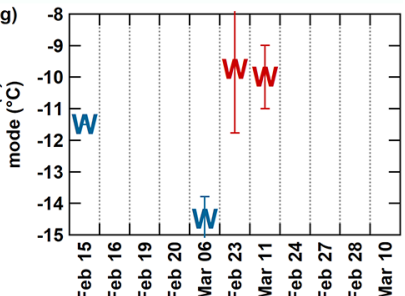

Figure 6. (a) Comparison of INCAS cumulative snow INP concentrations for northwest (blue) and southeast (red) within the same range of those reported by Stopelli et al. (2016) for measurements at JFJ during the 2012-2013 winter season. Summary of INCAS INP concentrations from aerosol (squares), cloud rime (circles), and snow samples (diamonds), including (b) freezing onset temperatures, (c) the temperature in which $10 \%$ of drops froze, and (d) the temperature in which $50 \%$ of the drops froze calculated from fraction frozen. From the $k(T)$ spectra, warm-mode temperatures are shown for (e) aerosol, (f) rime, and (g) snow samples. Blue, red, and green markers represent northwesterly cases, southeasterly cases, and SDE and BLI case days, respectively. Some data points overlap and thus plots may appear to not have the same number of points per sample.

bined, these results suggest a somewhat mixed-source sample and that 6 March may not be directly parallel to the other northwesterly cases. Transitioning back to a southeasterly case on 11 March, only the rime and snow unveiled a warm mode from air transported from similar regions to the 6 March sample. Additionally, OPS concentrations were very low (Fig. 1c). These results suggest the aerosols already nucleated cloud ice prior to reaching JFJ on 11 March (i.e., low ambient aerosol), where the aerosol did not contain a warm mode but rime and snow did.

When evaluating the SDE and BLI days, there is a bit of variability. On 24 February, clouds were present at JFJ (a cloud fraction of $37.5 \%$ ), but riming was insufficient to collect enough quantity for INP analysis and no snowfall occurred. Interestingly, the warm mode was the second highest for the aerosol sample, indicating a relatively large contribution of warm-temperature INPs as compared to the other samples from the study. Air mass transport was very similar to 23 February, signifying similar INP sources even though this day was characterized as an SDE, but it is probable that a slightly warmer $(-6.0$ as compared to $-9.8^{\circ} \mathrm{C}$ air temperature), drier ( $79 \%$ versus $89 \%$ relative humidity), and higher-pressure (649 versus $645 \mathrm{mbar}$ ) postfrontal system moved over JFJ on 24 February, inhibiting removal of warm-temperature INPs during transport relative to the day prior (corroborated by reanalysis from NCEPNCAR of geopotential height at $600 \mathrm{mbar}$ ). The BLI case of 28 February was very similar to 24 February in that (1) only an aerosol sample was collected and (2) the warm mode was much higher in concentration $(k(T))$ than the remaining samples. As compared to 27 February where a warm mode was not observed, 28 February was warmer $(-20.0$ as compared to $-26.2^{\circ} \mathrm{C}$ ), drier (52\% versus $62 \%$ ), higher pressure (635 versus $630 \mathrm{mbar}$ ), and had a warmer onset temperature $\left(-6.8\right.$ versus $\left.-14.8^{\circ} \mathrm{C}\right)$. Wind direction was slightly different: southeasterly $\left(153^{\circ}\right)$ on 27 February as compared to southwesterly on 28 February $\left(221^{\circ}\right)$. However, conditions were cloudier than the 23-24 February coupling and completely cloudy on 27 February (100\% and $66.7 \%$ cloud fraction on 27 and 28 February, respectively). Additionally, radon and OPS concentrations were the highest on 27-28 February as compared to the rest of the days during INCAS (Fig. 1c). Combined, these results suggest a very local, boundary layer source of INPs started on 27 February but were quickly depleted in the very cloudy conditions. Once clouds started to clear and a shift in frontal characteristics occurred, a similar source of very efficient warm-temperature INPs affected JFJ but was able to be observed in the aerosol.

\section{Conclusions and broader implications}

Aerosol, cloud rime, and snow samples were collected at the High Altitude Research Station Jungfraujoch during the INCAS field campaign in February and March 2018. The objectives of the study were to assess variability in wintertime INP sources found in cloudy environments and evaluate relationships between INPs found in the different sample materials. To directly compare air to liquid samples, characteristics of differential fraction frozen and INP spectra were compared in the context of cumulative INP spectra statistics, air mass transport and exposure to boundary layer or freetropospheric conditions, and local meteorology. Distinction between northwesterly and southeasterly conditions yielded 
differing results regarding INP efficiency and concentrations, biological versus nonbiological sources, and meteorological conditions at the sampling location. In general, cumulative INP concentrations were 3 to 20 times higher for all sample types when sources from the southeast infiltrated JFJ, while the INP spectra of the aerosol contained a warm mode but the presence of a warm mode was variable for the rime and snow depending on meteorological context.

In general, comprehensive measurements of INPs from aerosol, and rime and snow when possible, affords useful information to compare and explain the exchange between aerosols, clouds, and precipitation in the context of local- and regional-scale meteorology and transport conditions. Assessment of different INP spectral types, modality, and spectra statistics adds another dimension for qualitative and semiquantitative intercomparison of sampling days and evaluation of associations between aerosol, cloud, and precipitation sampling. Extending INP analyses past reporting cumulative concentrations affords more detailed information on the population of INPs and enables the comparison between samples from aerosols, clouds, precipitation, and beyond (seawater, soil, etc.). Using auxiliary measurements and air mass simulations, in addition to context provided by previous work at JFJ, we have addressed possible sources for INCAS. However, more detailed source apportionment work should be imminent to comprehensively characterize INP sources based on spectral features. Future studies should ideally use such statistical analyses in tandem with focused chemical and biological characterization assessments to provide direct linkages between INP spectral properties and sources. Such investigations could yield valuable information on INP sources and aerosol-cloud-precipitation interactions, which could then be used to improve process-level model parameterizations of such interactions by rendering quantitative information on INP source, efficiency, and abundance. Improving the understanding of aerosol impacts on clouds and precipitation will ultimately significantly enhance the understanding of the earth system with respect to cloud effects on the surface energy and water budgets to address future concerns of climate change and water availability.

Data availability. The INP data including drop freezing temperatures and cooling rates for the aerosol, rime, and snow INPs for each of the three tests per sample are available on PANGAEA (https: //doi.pangaea.de/10.1594/PANGAEA.902793, Creamean, 2019). Jungfraujoch meteorological data were obtained from MeteoSwiss (https://gate.meteoswiss.ch/idaweb/, last access: August 2018). HYSPLIT GDAS data were obtained from the NOAA ARL (https: //www.ready.noaa.gov, Draxler and Rolph, 2011).

Author contributions. JMC collected the samples, conducted the DFA sample analysis, conducted data analysis, and wrote the manuscript. $\mathrm{CM}$ and $\mathrm{FC}$ also contributed to collecting rime and snow samples. JMC, CM, and FC designed the experiments. NB provided quality-controlled OPS data. CM, NB, and FC helped with manuscript feedback and revision prior to submission.

Competing interests. The authors declare that they have no conflict of interest.

Disclaimer. The opinions expressed and arguments employed herein do not necessarily reflect the official views of the Swiss Government.

Acknowledgements. Radon measurements were performed as part of the Swiss contribution to ICOS (https://www.icos-ri.eu, last access: August 2018). Aerosol data were acquired by the Paul Scherrer Institute in the framework of the Global Atmosphere Watch (GAW) program funded by MeteoSwiss. We would like to thank Gabor Vali, one other anonymous reviewer, and Martin Gysel for their valuable feedback during the review process. Specifically, we would like to acknowledge and highlight Gabor Vali's contributions that provoked significant improvement of the manuscript during the review process. Further support was received from the ACTRIS2 project funded through the EU H2020-INFRAIA-2014-2015 program (grant agreement no. 654109) and the Swiss State Secretariat for Education, Research and Innovation (SERI; contract number 15.0159-1). We are grateful to the International Foundation High Altitude Research Stations Jungfraujoch and Gornergrat (HFSJG), 3012 Bern, Switzerland, for providing through its infrastructure comfortable access to mixed-phase clouds. Special thanks go to Joan and Martin Fischer, as well as Christine and Ruedi Käser, the custodians of the station. The authors gratefully acknowledge the NOAA Air Resources Laboratory (ARL) for the provision of the HYSPLIT transport and dispersion model and READY website (https://www.ready.noaa.gov, last access: August 2018) used in this publication.

Financial support. This research has been supported by the Swiss National Science Foundation (SNF) (grant nos. IZSEZ0_179151). The work of Claudia Mignani and Franz Conen on Jungfraujoch is made possible through SNF grant number 200021_169620.

Review statement. This paper was edited by Ryan Sullivan and reviewed by Gabor Vali and two anonymous referees.

\section{References}

Albrecht, B. A.: Aerosols, Cloud Microphysics, and Fractional Cloudiness, Science, 245, 1227-1230, https://doi.org/10.1126/science.245.4923.1227, 1989.

Alpert, P. A., Aller, J. Y., and Knopf, D. A.: Ice nucleation from aqueous $\mathrm{NaCl}$ droplets with and without marine diatoms, Atmos. Chem. Phys., 11, 5539-5555, https://doi.org/10.5194/acp11-5539-2011, 2011. 
Atkinson, J. D., Murray, B. J., Woodhouse, M. T., Whale, T. F., Baustian, K. J., Carslaw, K. S., Dobbie, S., O'Sullivan, D., and Malkin, T. L.: The importance of feldspar for ice nucleation by mineral dust in mixed-phase clouds, Nature, 498, 355-358, https://doi.org/10.1038/nature12278, 2013.

Baltensperger, U., Gäggeler, H. W., Jost, D. T., Lugauer, M., Schwikowski, M., Weingartner, E., and Seibert, P.: Aerosol climatology at the high-alpine site Jungfraujoch, Switzerland, J. Geophys. Res.-Atmos., 102, 19707-19715, https://doi.org/10.1029/97JD00928, 1997.

Beck, A., Henneberger, J., Fugal, J. P., David, R. O., Lacher, L., and Lohmann, U.: Impact of surface and near-surface processes on ice crystal concentrations measured at mountaintop research stations, Atmos. Chem. Phys., 18, 8909-8927, https://doi.org/10.5194/acp-18-8909-2018, 2018.

Bergeron, T.: On the physics of cloud and precipitation, 5th Assembly of the U.G.G.I., Paul Dupont, Paris, 1935.

Beydoun, H., Polen, M., and Sullivan, R. C.: A new multicomponent heterogeneous ice nucleation model and its application to Snomax bacterial particles and a Snomax-illite mineral particle mixture, Atmos. Chem. Phys., 17, 13545-13557, https://doi.org/10.5194/acp-17-13545-2017, 2017.

Bigg, E. K.: The Supercooling of Water, P. Phys. Soc. Lond. B, 66, 688-694, https://doi.org/10.1088/0370-1301/66/8/309, 1953.

Boose, Y., Sierau, B., Garcáa, M. I., Rodríguez, S., Alastuey, A., Linke, C., Schnaiter, M., Kupiszewski, P., Kanji, Z. A., and Lohmann, U.: Ice nucleating particles in the Saharan Air Layer, Atmos. Chem. Phys., 16, 9067-9087, https://doi.org/10.5194/acp-16-9067-2016, 2016.

Boucher, O., Randall, D., Artaxo, P., Bretherton, C., Feingold, G., Forster, P., Kerminen, V.-M., Kondo, Y., Liao, H., Lohmann, U., Rasch, P., Satheesh, S. K., Sherwood, S., Stevens, B., and Zhang, X. Y.: Clouds and Aerosols, in: Climate Change 2013: The Physical Science Basis. Contribution of Working Group I to the Fifth Assessment Report of the Intergovernmental Panel on Climate Change, edited by: Stocker, T. F., Qin, D., Plattner, G.-K., Tignor, M., Allen, S. K., Boschung, J., Nauels, A., Xia, Y., Bex, V., and Midgley, P. M., Cambridge University Press, Cambridge, UK and New York, NY, USA, 571-658, 2013.

Bowers, R. M., Lauber, C. L., Wiedinmyer, C., Hamady, M., Hallar, A. G., Fall, R., Knight, R., and Fierer, N.: Characterization of Airborne Microbial Communities at a High-Elevation Site and Their Potential To Act as Atmospheric Ice Nuclei, Appl. Environ. Microbiol., 75, 5121-5130, https://doi.org/10.1128/Aem.0044709, 2009.

Bukowiecki, N., Richard, A., Furger, M., Weingartner, E., Aguirre, M., Huthwelker, T., Lienemann, P., Gehrig, R., and Baltensperger, U.: Deposition Uniformity and Particle Size Distribution of Ambient Aerosol Collected with a Rotating Drum Impactor, Aerosol Sci. Tech., 43, 891-901, https://doi.org/10.1080/02786820903002431, 2009.

Bukowiecki, N., Weingartner, E., Gysel, M., Coen, M. C., Zieger, P., Herrmann, E., Steinbacher, M., Gäggeler, H. W., and Baltensperger, U.: A Review of More than 20 Years of Aerosol Observation at the High Altitude Research Station Jungfraujoch, Switzerland (3580 m asl), Aerosol Air Qual. Res., 16, 764-788, https://doi.org/10.4209/aaqr.2015.05.0305, 2016.

Burrows, S. M., Butler, T., Jöckel, P., Tost, H., Kerkweg, A., Pöschl, U., and Lawrence, M. G.: Bacteria in the global at- mosphere - Part 2: Modeling of emissions and transport between different ecosystems, Atmos. Chem. Phys., 9, 9281-9297, https://doi.org/10.5194/acp-9-9281-2009, 2009a.

Burrows, S. M., Elbert, W., Lawrence, M. G., and Pöschl, U.: Bacteria in the global atmosphere - Part 1: Review and synthesis of literature data for different ecosystems, Atmos. Chem. Phys., 9, 9263-9280, https://doi.org/10.5194/acp-9-9263-2009, 2009b.

Burrows, S. M., Hoose, C., Pöschl, U., and Lawrence, M. G.: Ice nuclei in marine air: biogenic particles or dust?, Atmos. Chem. Phys., 13, 245-267, https://doi.org/10.5194/acp-13-2452013, 2013.

Cahill, T. A., Feeney, P. J., and Eldred, R. A.: Size Time Composition Profile of Aerosols Using the Drum Sampler, Nucl. Instrum. Meth. B, 22, 344-348, https://doi.org/10.1016/0168$583 x(87) 90355-7,1987$.

Chambers, S. D., Williams, A. G., Conen, F., Griffiths, A. D., Reimann, S., Steinbacher, M., Krummel, P. B., Steele, L. P., van der Schoot, M. V., Galbally, I. E., Molloy, S. B., and Barnes, J. E.: Towards a Universal "Baseline" Characterisation of Air Masses for High- and Low-Altitude Observing Stations Using Radon-222, Aerosol Air Qual. Res., 16, 885-899, https://doi.org/10.4209/aaqr.2015.06.0391, 2016.

Christner, B. C., Morris, C. E., Foreman, C. M., Cai, R. M., and Sands, D. C.: Ubiquity of biological ice nucleators in snowfall, Science, 319, 1214-1214, https://doi.org/10.1126/science.1149757, 2008.

Collaud Coen, M., Weingartner, E., Schaub, D., Hueglin, C., Corrigan, C., Henning, S., Schwikowski, M., and Baltensperger, U.: Saharan dust events at the Jungfraujoch: detection by wavelength dependence of the single scattering albedo and first climatology analysis, Atmos. Chem. Phys., 4, 2465-2480, https://doi.org/10.5194/acp-4-2465-2004, 2004.

Collaud Coen, M., Weingartner, E., Furger, M., Nyeki, S., Prévôt, A. S. H., Steinbacher, M., and Baltensperger, U.: Aerosol climatology and planetary boundary influence at the Jungfraujoch analyzed by synoptic weather types, Atmos. Chem. Phys., 11, 5931-5944, https://doi.org/10.5194/acp-11-5931-2011, 2011.

Collaud Coen, M., Andrews, E., Aliaga, D., Andrade, M., Angelov, H., Bukowiecki, N., Ealo, M., Fialho, P., Flentje, H., Hallar, A. G., Hooda, R., Kalapov, I., Krejci, R., Lin, N.-H., Marinoni, A., Ming, J., Nguyen, N. A., Pandolfi, M., Pont, V., Ries, L., Rodríguez, S., Schauer, G., Sellegri, K., Sharma, S., Sun, J., Tunved, P., Velasquez, P., and Ruffieux, D.: Identification of topographic features influencing aerosol observations at high altitude stations, Atmos. Chem. Phys., 18, 12289-12313, https://doi.org/10.5194/acp-18-12289-2018, 2018.

Coluzza, I., Creamean, J., Rossi, M., Wex, H., Alpert, P., Bianco, V., Boose, Y., Dellago, C., Felgitsch, L., FröhlichNowoisky, J., Herrmann, H., Jungblut, S., Kanji, Z., Menzl, G., Moffett, B., Moritz, C., Mutzel, A., Pöschl, U., Schauperl, M., Scheel, J., Stopelli, E., Stratmann, F., Grothe, H., and Schmale, D.: Perspectives on the Future of Ice Nucleation Research: Research Needs and Unanswered Questions Identified from Two International Workshops, Atmosphere, 8, 138, https://doi.org/10.3390/atmos8080138, 2017.

Conen, F. and Yakutin, M. V.: Soils rich in biological icenucleating particles abound in ice-nucleating macromolecules likely produced by fungi, Biogeosciences, 15, 4381-4385, https://doi.org/10.5194/bg-15-4381-2018, 2018. 
Conen, F., Morris, C. E., Leifeld, J., Yakutin, M. V., and Alewell, C.: Biological residues define the ice nucleation properties of soil dust, Atmos. Chem. Phys., 11, 9643-9648, https://doi.org/10.5194/acp-11-9643-2011, 2011.

Conen, F., Rodriguez, S., Huglin, C., Henne, S., Herrmann, E., Bukowiecki, N., and Alewell, C.: Atmospheric ice nuclei at the high-altitude observatory Jungfraujoch, Switzerland, Tellus B, 67, 1, https://doi.org/10.3402/tellusb.v67.25014, 2015.

Creamean, J. M.: Ice nucleating particle data from winter 2018 at Jungfraujoch, PANGAEA, https://doi.org/10.1594/PANGAEA.902793, last access: 20 June 2019.

Creamean, J. M., Suski, K. J., Rosenfeld, D., Cazorla, A., DeMott, P. J., Sullivan, R. C., White, A. B., Ralph, F. M., Minnis, P., Comstock, J. M., Tomlinson, J. M., and Prather, K. A.: Dust and Biological Aerosols from the Sahara and Asia Influence Precipitation in the Western U.S., Science, 339, 1572-1578, https://doi.org/10.1126/science.1227279, 2013.

Creamean, J. M., Kirpes, R. M., Pratt, K. A., Spada, N. J., Maahn, M., de Boer, G., Schnell, R. C., and China, S.: Marine and terrestrial influences on ice nucleating particles during continuous springtime measurements in an Arctic oilfield location, Atmos. Chem. Phys., 18, 18023-18042, https://doi.org/10.5194/acp-1818023-2018, 2018a.

Creamean, J. M., Primm, K. M., Tolbert, M. A., Hall, E. G., Wendell, J., Jordan, A., Sheridan, P. J., Smith, J., and Schnell, R. C.: HOVERCAT: a novel aerial system for evaluation of aerosol-cloud interactions, Atmos. Meas. Tech., 11, 3969-3985, https://doi.org/10.5194/amt-11-3969-2018, 2018 b.

Cziczo, D. J., Ladino, L., Boose, Y., Kanji, Z. A., Kupiszewski, P., Lance, S., Mertes, S., and Wex, H.: Measurements of Ice Nucleating Particles and Ice Residuals, Meteor. Mon., 58, 8.1-8.13, https://doi.org/10.1175/amsmonographs-d-16-0008.1, 2017.

DeMott, P. J., Chen, Y., Kreidenweis, S. M., Rogers, D. C., and Sherman, D. E.: Ice formation by black carbon particles, Geophys. Res. Lett., 26, 2429-2432, https://doi.org/10.1029/1999g1900580, 1999.

DeMott, P. J., Prenni, A. J., Liu, X., Kreidenweis, S. M., Petters, M. D., Twohy, C. H., Richardson, M. S., Eidhammer, T., and Rogers, D. C.: Predicting global atmospheric ice nuclei distributions and their impacts on climate, P. Natl. Acad. Sci. USA, 107, 1121711222, https://doi.org/10.1073/pnas.0910818107, 2010.

DeMott, P. J., Hill, T. C. J., McCluskey, C. S., Prather, K. A., Collins, D. B., Sullivan, R. C., Ruppel, M. J., Mason, R. H., Irish, V. E., Lee, T., Hwang, C. Y., Rhee, T. S., Snider, J. R., McMeeking, G. R., Dhaniyala, S., Lewis, E. R., Wentzell, J. J. B., Abbatt, J., Lee, C., Sultana, C. M., Ault, A. P., Axson, J. L., Martinez, M. D., Venero, I., Santos-Figueroa, G., Stokes, M. D., Deane, G. B., Mayol-Bracero, O. L., Grassian, V. H., Bertram, T. H., Bertram, A. K., Moffett, B. F., and Franc, G. D.: Sea spray aerosol as a unique source of ice nucleating particles, P. Natl. Acad. Sci. USA, 113, 5797-5803, https://doi.org/10.1073/pnas.1514034112, 2016.

DeMott, P. J., Möhler, O., Cziczo, D. J., Hiranuma, N., Petters, M. D., Petters, S. S., Belosi, F., Bingemer, H. G., Brooks, S. D., Budke, C., Burkert-Kohn, M., Collier, K. N., Danielczok, A., Eppers, O., Felgitsch, L., Garimella, S., Grothe, H., Herenz, P., Hill, T. C. J., Höhler, K., Kanji, Z. A., Kiselev, A., Koop, T., Kristensen, T. B., Krüger, K., Kulkarni, G., Levin, E. J. T., Murray,
B. J., Nicosia, A., O’Sullivan, D., Peckhaus, A., Polen, M. J., Price, H. C., Reicher, N., Rothenberg, D. A., Rudich, Y., Santachiara, G., Schiebel, T., Schrod, J., Seifried, T. M., Stratmann, F., Sullivan, R. C., Suski, K. J., Szakáll, M., Taylor, H. P., Ullrich, R., Vergara-Temprado, J., Wagner, R., Whale, T. F., Weber, D., Welti, A., Wilson, T. W., Wolf, M. J., and Zenker, J.: The Fifth International Workshop on Ice Nucleation phase 2 (FIN-02): laboratory intercomparison of ice nucleation measurements, Atmos. Meas. Tech., 11, 6231-6257, https://doi.org/10.5194/amt11-6231-2018, 2018.

Despres, V. R., Huffman, J. A., Burrows, S. M., Hoose, C., Safatov, A. S., Buryak, G., Fröhlich-Nowoisky, J., Elbert, W., Andreae, M. O., Pöschl, U., and Jaenicke, R.: Primary biological aerosol particles in the atmosphere: a review, Tellus B, 64, 1, https://doi.org/10.3402/tellusb.v64i0.15598, 2012.

Draxler, R. R.: HYSPLIT4 user's guide, NOAA Air Resources Laboratory, Silver Spring, MD, 1999.

Draxler, R. R. and Rolph, G.: HYSPLIT (HYbrid Single-Particle Lagrangian Integrated Trajectory) Model access via NOAA ARL READY website, available at: https://www.ready.noaa.gov/ HYSPLIT.php, last access: August 2018), NOAA Air Resources Laboratory, Silver Spring, MD, 2011.

Eriksen Hammer, S., Mertes, S., Schneider, J., Ebert, M., Kandler, K., and Weinbruch, S.: Composition of ice particle residuals in mixed-phase clouds at Jungfraujoch (Switzerland): enrichment and depletion of particle groups relative to total aerosol, Atmos. Chem. Phys., 18, 13987-14003, https://doi.org/10.5194/acp-1813987-2018, 2018.

Fridlind, A. M., Diedenhoven, B. v., Ackerman, A. S., Avramov, A., Mrowiec, A., Morrison, H., Zuidema, P., and Shupe, M. D.: A FIRE-ACE/SHEBA Case Study of Mixed-Phase Arctic Boundary Layer Clouds: Entrainment Rate Limitations on Rapid Primary Ice Nucleation Processes, J. Atmos. Sci., 69, 365-389, https://doi.org/10.1175/jas-d-11-052.1, 2012.

Fröhlich-Nowoisky, J., Burrows, S. M., Xie, Z., Engling, G., Solomon, P. A., Fraser, M. P., Mayol-Bracero, O. L., Artaxo, P., Begerow, D., Conrad, R., Andreae, M. O., Després, V. R., and Pöschl, U.: Biogeography in the air: fungal diversity over land and oceans, Biogeosciences, 9, 1125-1136, https://doi.org/10.5194/bg-9-1125-2012, 2012.

Fröhlich-Nowoisky, J., Hill, T. C. J., Pummer, B. G., Yordanova, P., Franc, G. D., and Pöschl, U.: Ice nucleation activity in the widespread soil fungus Mortierella alpina, Biogeosciences, 12, 1057-1071, https://doi.org/10.5194/bg-12-1057-2015, 2015.

Fröhlich-Nowoisky, J., Kampf, C. J., Weber, B., Huffman, J. A., Pohlker, C., Andreae, M. O., Lang-Yona, N., Burrows, S. M., Gunthe, S. S., Elbert, W., Su, H., Hoor, P., Thines, E., Hoffmann, T., Despres, V. R., and Pöschl, U.: Bioaerosols in the Earth system: Climate, health, and ecosystem interactions, Atmos. Res., 182, 346-376, https://doi.org/10.1016/j.atmosres.2016.07.018, 2016.

Ganguly, M., Dib, S., and Ariya, P. A.: Purely Inorganic Highly Efficient Ice Nucleating Particle, ACS Omega, 3, 3384-3395, https://doi.org/10.1021/acsomega.7b01830, 2018.

Griffiths, A. D., Conen, F., Weingartner, E., Zimmermann, L., Chambers, S. D., Williams, A. G., and Steinbacher, M.: Surfaceto-mountaintop transport characterised by radon observations at the Jungfraujoch, Atmos. Chem. Phys., 14, 12763-12779, https://doi.org/10.5194/acp-14-12763-2014, 2014. 
Hader, J. D., Wright, T. P., and Petters, M. D.: Contribution of pollen to atmospheric ice nuclei concentrations, Atmos. Chem. Phys., 14, 5433-5449, https://doi.org/10.5194/acp-145433-2014, 2014.

Hara, K., Maki, T., Kakikawa, M., Kobayashi, F., and Matsuki, A.: Effects of different temperature treatments on biological ice nuclei in snow samples, Atmos. Environ., 140, 415-419, https://doi.org/10.1016/j.atmosenv.2016.06.011, 2016.

Herrmann, E., Weingartner, E., Henne, S., Vuilleumier, L., Bukowiecki, N., Steinbacher, M., Conen, F., Coen, M. C., Hammer, E., Juranyi, Z., Baltensperger, U., and Gysel, M.: Analysis of long-term aerosol size distribution data from Jungfraujoch with emphasis on free tropospheric conditions, cloud influence, and air mass transport, J. Geophys. Res.-Atmos., 120, 94599480, https://doi.org/10.1002/2015jd023660, 2015.

Hill, T. C. J., DeMott, P. J., Tobo, Y., Fröhlich-Nowoisky, J., Moffett, B. F., Franc, G. D., and Kreidenweis, S. M.: Sources of organic ice nucleating particles in soils, Atmos. Chem. Phys., 16, 7195-7211, https://doi.org/10.5194/acp-16-7195-2016, 2016.

Hoose, C. and Möhler, O.: Heterogeneous ice nucleation on atmospheric aerosols: a review of results from laboratory experiments, Atmos. Chem. Phys., 12, 9817-9854, https://doi.org/10.5194/acp-12-9817-2012, 2012.

Hu, W., Niu, H. Y., Murata, K., Wu, Z. J., Hu, M., Kojima, T., and Zhang, D. Z.: Bacteria in atmospheric waters: Detection, characteristics and implications, Atmos. Environ., 179, 201-221, https://doi.org/10.1016/j.atmosenv.2018.02.026, 2018.

Hummel, M., Hoose, C., Gallagher, M., Healy, D. A., Huffman, J. A., O'Connor, D., Pöschl, U., Pöhlker, C., Robinson, N. H., Schnaiter, M., Sodeau, J. R., Stengel, M., Toprak, E., and Vogel, H.: Regional-scale simulations of fungal spore aerosols using an emission parameterization adapted to local measurements of fluorescent biological aerosol particles, Atmos. Chem. Phys., 15, 6127-6146, https://doi.org/10.5194/acp-15-6127-2015, 2015.

Jaenicke, R.: Atmospheric aerosols and global climate, J. Aerosol Sci., 11, 577-588, https://doi.org/10.1016/0021-8502(80)901317, 1980 .

Jaenicke, R.: Abundance of Cellular Material and Proteins in the Atmosphere, Science, 308, 73-73, https://doi.org/10.1126/science.1106335, 2005.

Jaenicke, R., Matthias-Maser, S., and Gruber, S.: Omnipresence of biological material in the atmosphere, Environ. Chem., 4, 217 220, https://doi.org/10.1071/EN07021, 2007.

Kanji, Z. A., Ladino, L. A., Wex, H., Boose, Y., BurkertKohn, M., Cziczo, D. J., and Krämer, M.: Overview of Ice Nucleating Particles, Meteorol. Monogr., 58, 1.1-1.33, https://doi.org/10.1175/amsmonographs-d-16-0006.1, 2017.

Kellogg, C. A. and Griffin, D. W.: Aerobiology and the global transport of desert dust, Trends Ecol. Evol., 21, 638-644, https://doi.org/10.1016/j.tree.2006.07.004, 2006.

Kieft, T. L.: Ice Nucleation Activity in Lichens, Appl. Environ. Microbiol., 54, 1678-1681, 1988.

Knopf, D. A., Alpert, P. A., Wang, B., and Aller, J. Y.: Stimulation of ice nucleation by marine diatoms, Nat. Geosci., 4, 88, https://doi.org/10.1038/ngeo1037, 2010.

Korolev, A., McFarquhar, G., Field, P. R., Franklin, C., Lawson, P., Wang, Z., Williams, E., Abel, S. J., Axisa, D., Borrmann, S., Crosier, J., Fugal, J., Krämer, M., Lohmann, U., Schlenczek, O., Schnaiter, M., and Wendisch, M.: Mixed-Phase Clouds:
Progress and Challenges, Meteorol. Monogr., 58, 5.1-5.50, https://doi.org/10.1175/amsmonographs-d-17-0001.1, 2017.

Lacher, L., Lohmann, U., Boose, Y., Zipori, A., Herrmann, E., Bukowiecki, N., Steinbacher, M., and Kanji, Z. A.: The Horizontal Ice Nucleation Chamber (HINC): INP measurements at conditions relevant for mixed-phase clouds at the High Altitude Research Station Jungfraujoch, Atmos. Chem. Phys., 17, 15199_ 15224, https://doi.org/10.5194/acp-17-15199-2017, 2017.

Lacher, L., DeMott, P. J., Levin, E. J. T., Suski, K. J., Boose, Y., Zipori, A., Herrmann, E., Bukowiecki, N., Steinbacher, M., Gute, E., Abbatt, J. P. D., Lohmann, U., and Kanji, Z. A.: Background Free-Tropospheric Ice Nucleating Particle Concentrations at Mixed-Phase Cloud Conditions, J. Geophys. Res.-Atmos., 123, 10506-10525, https://doi.org/10.1029/2018JD028338, 2018a.

Lacher, L., Steinbacher, M., Bukowiecki, N., Herrmann, E., Zipori, A., and Kanji, Z. A.: Impact of Air Mass Conditions and Aerosol Properties on Ice Nucleating Particle Concentrations at the High Altitude Research Station Jungfraujoch, Atmosphere, 9, 363, https://doi.org/10.3390/atmos9090363, 2018 b.

Langham, E. J. and Mason, B. J.: The Heterogeneous and Homogeneous Nucleation of Supercooled Water, Proc. R. Soc. Lon. Ser.-A, 247, 493, https://doi.org/10.1098/rspa.1958.0207, 1958.

Lloyd, G., Choularton, T. W., Bower, K. N., Gallagher, M. W., Connolly, P. J., Flynn, M., Farrington, R., Crosier, J., Schlenczek, O., Fugal, J., and Henneberger, J.: The origins of ice crystals measured in mixed-phase clouds at the highalpine site Jungfraujoch, Atmos. Chem. Phys., 15, 12953-12969, https://doi.org/10.5194/acp-15-12953-2015, 2015.

Lohmann, U., Henneberger, J., Henneberg, O., Fugal, J. P., Bühl, J., and Kanji, Z. A.: Persistence of orographic mixed-phase clouds, Geophys. Res. Lett., 43, 10512-10519, https://doi.org/10.1002/2016GL071036, 2016.

Mason, R. H., Si, M., Chou, C., Irish, V. E., Dickie, R., Elizondo, P., Wong, R., Brintnell, M., Elsasser, M., Lassar, W. M., Pierce, K. M., Leaitch, W. R., MacDonald, A. M., Platt, A., ToomSauntry, D., Sarda-Estève, R., Schiller, C. L., Suski, K. J., Hill, T. C. J., Abbatt, J. P. D., Huffman, J. A., DeMott, P. J., and Bertram, A. K.: Size-resolved measurements of ice-nucleating particles at six locations in North America and one in Europe, Atmos. Chem. Phys., 16, 1637-1651, https://doi.org/10.5194/acp16-1637-2016, 2016.

McCluskey, C. S., Hill, T. C. J., Malfatti, F., Sultana, C. M., Lee, C., Santander, M. V., Beall, C. M., Moore, K. A., Cornwell, G. C., Collins, D. B., Prather, K. A., Jayarathne, T., Stone, E. A., Azam, F., Kreidenweis, S. M., and DeMott, P. J.: A Dynamic Link between Ice Nucleating Particles Released in Nascent Sea Spray Aerosol and Oceanic Biological Activity during Two Mesocosm Experiments, J. Atmos. Sci., 74, 151-166, https://doi.org/10.1175/Jas-D-16-0087.1, 2017.

Mignani, C., Creamean, J. M., Zimmermann, L., Alewell, C., and Conen, F.: New type of evidence for secondary ice formation at around $-15^{\circ} \mathrm{C}$ in mixed-phase clouds, Atmos. Chem. Phys., 19, 877-886, https://doi.org/10.5194/acp-19-877-2019, 2019.

Morris, C. E., Georgakopoulos, D. G., and Sands, D. C.: Ice nucleation active bacteria and their potential role in precipitation, J. Phys. IV, 121, 87-103, https://doi.org/10.1051/jp4:2004121004, 2004.

Morris, C. E., Sands, D. C., Bardin, M., Jaenicke, R., Vogel, B., Leyronas, C., Ariya, P. A., and Psenner, R.: Microbiology and 
atmospheric processes: research challenges concerning the impact of airborne micro-organisms on the atmosphere and climate, Biogeosciences, 8, 17-25, https://doi.org/10.5194/bg-8-17-2011, 2011.

Morris, C. E., Conen, F., Huffman, J. A., Phillips, V., Pöschl, U., and Sands, D. C.: Bioprecipitation: a feedback cycle linking Earth history, ecosystem dynamics and land use through biological ice nucleators in the atmosphere, Glob. Change Biol., 20, 341-351, https://doi.org/10.1111/gcb.12447, 2014.

Morris, C. E., Soubeyrand, S., Bigg, E. K., Creamean, J. M., and Sands, D. C.: Mapping Rainfall Feedback to Reveal the Potential Sensitivity of Precipitation to Biological Aerosols, B. Am. Meteorol. Soc., 98, 1109-1118, https://doi.org/10.1175/BAMSD-15-00293.1, 2017.

Mossop, S. C. and Thorndike, N. S. C.: The Use of Membrane Filters in Measurements of Ice Nucleus Concentration. I. Effect of Sampled Air Volume, J. Appl. Meteorol., 5, 474-480, https://doi.org/10.1175/15200450(1966)005<0474:tuomfi>2.0.co;2, 1966.

Murray, B. J., O'Sullivan, D., Atkinson, J. D., and Webb, M. E.: Ice nucleation by particles immersed in supercooled cloud droplets, Chem. Soc. Rev., 41, 6519-6554, https://doi.org/10.1039/C2cs35200a, 2012.

O'Sullivan, D., Murray, B. J., Malkin, T. L., Whale, T. F., Umo, N. S., Atkinson, J. D., Price, H. C., Baustian, K. J., Browse, J., and Webb, M. E.: Ice nucleation by fertile soil dusts: relative importance of mineral and biogenic components, Atmos. Chem. Phys., 14, 1853-1867, https://doi.org/10.5194/acp-141853-2014, 2014.

O'Sullivan, D., Murray, B. J., Ross, J. F., and Webb, M. E.: The adsorption of fungal ice-nucleating proteins on mineral dusts: a terrestrial reservoir of atmospheric ice-nucleating particles, Atmos. Chem. Phys., 16, 7879-7887, https://doi.org/10.5194/acp16-7879-2016, 2016.

Petters, M. D. and Wright, T. P.: Revisiting ice nucleation from precipitation samples, Geophys. Res. Lett., 42, 8758-8766, https://doi.org/10.1002/2015g1065733, 2015.

Polen, M., Brubaker, T., Somers, J., and Sullivan, R. C.: Cleaning up our water: reducing interferences from nonhomogeneous freezing of "pure" water in droplet freezing assays of ice-nucleating particles, Atmos. Meas. Tech., 11, 5315-5334, https://doi.org/10.5194/amt-11-5315-2018, 2018.

Price, H. C., Baustian, K. J., McQuaid, J. B., Blyth, A., Bower, K. N., Choularton, T., Cotton, R. J., Cui, Z., Field, P. R., Gallagher, M., Hawker, R., Merrington, A., Miltenberger, A., Neely, R. R., Parker, S. T., Rosenberg, P. D., Taylor, J. W., Trembath, J., Vergara-Temprado, J., Whale, T. F., Wilson, T. W., Young, G., and Murray, B. J.: Atmospheric Ice-Nucleating Particles in the Dusty Tropical Atlantic, J. Geophys. Res.-Atmos., 123, 21752193, https://doi.org/10.1002/2017jd027560, 2018.

Reche, I., D'Orta, G., Mladenov, N., Winget, D. M., and Suttle, C. A.: Deposition rates of viruses and bacteria above the atmospheric boundary layer, Isme J., 12, 1154-1162, https://doi.org/10.1038/s41396-017-0042-4, 2018.

Sahyoun, M., Korsholm, U. S., Sorensen, J. H., Santl-Temkiv, T., Finster, K., Gosewinkel, U., and Nielsen, N. W.: Impact of bacterial ice nucleating particles on weather predicted by a numerical weather prediction model, Atmos. Environ., 170, 33-44, https://doi.org/10.1016/j.atmosenv.2017.09.029, 2017.
Schnell, R. C. and Vali, G.: Biogenic Ice Nuclei .1. Terrestrial and Marine Sources, J. Atmos. Sci., 33, 1554-1564, https://doi.org/10.1175/15200469(1976)033<1554:Binpit>2.0.Co;2, 1976.

Stein, A. F., Draxler, R. R., Rolph, G. D., Stunder, B. J. B., Cohen, M. D., and Ngan, F.: NOAA's HYSPLIT Atmospheric Transport and Dispersion Modeling System, B. Am. Meteorol. Soc., 96, 2059-2077, https://doi.org/10.1175/bams-d-14-00110.1, 2015.

Stopelli, E., Conen, F., Zimmermann, L., Alewell, C., and Morris, C. E.: Freezing nucleation apparatus puts new slant on study of biological ice nucleators in precipitation, Atmos. Meas. Tech., 7, 129-134, https://doi.org/10.5194/amt-7-129-2014, 2014.

Stopelli, E., Conen, F., Morris, C. E., Herrmann, E., Bukowiecki, N., and Alewell, C.: Ice nucleation active particles are efficiently removed by precipitating clouds, Sci. Rep.-UK, 5, 16433, https://doi.org/10.1038/srep16433, 2015.

Stopelli, E., Conen, F., Morris, C. E., Herrmann, E., Henne, S., Steinbacher, M., and Alewell, C.: Predicting abundance and variability of ice nucleating particles in precipitation at the highaltitude observatory Jungfraujoch, Atmos. Chem. Phys., 16, 8341-8351, https://doi.org/10.5194/acp-16-8341-2016, 2016.

Stopelli, E., Conen, F., Guilbaud, C., Zopfi, J., Alewell, C., and Morris, C. E.: Ice nucleators, bacterial cells and Pseudomonas syringae in precipitation at Jungfraujoch, Biogeosciences, 14, 1189-1196, https://doi.org/10.5194/bg-14-1189-2017, 2017.

Storelvmo, T., Hoose, C., and Eriksson, P.: Global modeling of mixed-phase clouds: The albedo and lifetime effects of aerosols, J. Geophys. Res.-Atmos., 116, D05207, https://doi.org/10.1029/2010JD014724, 2011.

Suski, K. J., Hill, T. C. J., Levin, E. J. T., Miller, A., DeMott, P. J., and Kreidenweis, S. M.: Agricultural harvesting emissions of ice-nucleating particles, Atmos. Chem. Phys., 18, 13755-13771, https://doi.org/10.5194/acp-18-13755-2018, 2018.

Tesson, S. V. M., Skjøth, C. A., Šantl-Temkiv, T., and Löndahl, J.: Airborne Microalgae: Insights, Opportunities and Challenges, Appl. Environ. Microbiol., 82, 1978-1991, https://doi.org/10.1128/aem.03333-15, 2016.

Tobo, Y.: An improved approach for measuring immersion freezing in large droplets over a wide temperature range, Sci. Rep.-UK, 6, 32930, https://doi.org/10.1038/srep32930, 2016.

Tobo, Y., DeMott, P. J., Hill, T. C. J., Prenni, A. J., SwobodaColberg, N. G., Franc, G. D., and Kreidenweis, S. M.: Organic matter matters for ice nuclei of agricultural soil origin, Atmos. Chem. Phys., 14, 8521-8531, https://doi.org/10.5194/acp14-8521-2014, 2014.

Twohy, C. H., McMeeking, G. R., DeMott, P. J., McCluskey, C. S., Hill, T. C. J., Burrows, S. M., Kulkarni, G. R., Tanarhte, M., Kafle, D. N., and Toohey, D. W.: Abundance of fluorescent biological aerosol particles at temperatures conducive to the formation of mixed-phase and cirrus clouds, Atmos. Chem. Phys., 16, 8205-8225, https://doi.org/10.5194/acp-16-8205-2016, 2016.

Twomey, S.: The Influence of Pollution on the Shortwave Albedo of Clouds, J. Atmos. Sci., 34, 1149-1152, https://doi.org/10.1175/15200469(1977)034<1149:tiopot>2.0.co;2, 1977.

Vali, G.: Quantitative Evaluation of Experimental Results an the Heterogeneous Freezing Nucleation of Supercooled Liquids, J. Atmos. Sci., 28, 402-409, https://doi.org/10.1175/15200469(1971)028<0402:qeoera>2.0.co;2, 1971. 
Vali, G.: Revisiting the differential freezing nucleus spectra derived from drop-freezing experiments: methods of calculation, applications, and confidence limits, Atmos. Meas. Tech., 12, 12191231, https://doi.org/10.5194/amt-12-1219-2019, 2019.

Vali, G. and Stansbury, E. J.: Time-Dependent Characteristics of Heterogeneous Nucleation of Ice, Can. J. Phys., 44, 477-502, https://doi.org/10.1139/p66-044, 1966.

Vali, G., Christensen, M., Fresh, R. W., Galyan, E. L., Maki, L. R., and Schnell, R. C.: Biogenic Ice Nuclei .2. Bacterial Sources, J. Atmos. Sci., 33, 1565-1570, https://doi.org/10.1175/15200469(1976)033<1565:Binpib>2.0.Co;2, 1976.

Vali, G., DeMott, P. J., Möhler, O., and Whale, T. F.: Technical Note: A proposal for ice nucleation terminology, Atmos. Chem. Phys., 15, 10263-10270, https://doi.org/10.5194/acp-15-102632015, 2015.

von Blohn, N., Mitra, S. K., Diehl, K., and Borrmann, S.: The ice nucleating ability of pollen: Part III: New laboratory studies in immersion and contact freezing modes including more pollen types, Atmos. Res., 78, 182-189, https://doi.org/10.1016/j.atmosres.2005.03.008, 2005.

Weingartner, E., Nyeki, S., and Baltensperger, U.: Seasonal and diurnal variation of aerosol size distributions $(10<D<750 \mathrm{~nm})$ at a high-alpine site (Jungfraujoch $3580 \mathrm{~m}$ asl), J. Geophys. Res.-Atmos., 104, 26809-26820, https://doi.org/10.1029/1999jd900170, 1999.
Wex, H., Augustin-Bauditz, S., Boose, Y., Budke, C., Curtius, J., Diehl, K., Dreyer, A., Frank, F., Hartmann, S., Hiranuma, N., Jantsch, E., Kanji, Z. A., Kiselev, A., Koop, T., Möhler, O., Niedermeier, D., Nillius, B., Rösch, M., Rose, D., Schmidt, C., Steinke, I., and Stratmann, F.: Intercomparing different devices for the investigation of ice nucleating particles using Snomax ${ }^{\circledR}$ as test substance, Atmos. Chem. Phys., 15, 14631485, https://doi.org/10.5194/acp-15-1463-2015, 2015.

Wilson, T. W., Ladino, L. A., Alpert, P. A., Breckels, M. N., Brooks, I. M., Browse, J., Burrows, S. M., Carslaw, K. S., Huffman, J. A., Judd, C., Kilthau, W. P., Mason, R. H., McFiggans, G., Miller, L. A., Najera, J. J., Polishchuk, E., Rae, S., Schiller, C. L., Si, M., Temprado, J. V., Whale, T. F., Wong, J. P. S., Wurl, O., Yakobi-Hancock, J. D., Abbatt, J. P. D., Aller, J. Y., Bertram, A. K., Knopf, D. A., and Murray, B. J.: A marine biogenic source of atmospheric ice-nucleating particles, Nature, 525, 234-238, https://doi.org/10.1038/nature14986, 2015.

Wright, T. P. and Petters, M. D.: The role of time in heterogeneous freezing nucleation, J. Geophys. Res.-Atmos., 118, 3731-3743, https://doi.org/10.1002/jgrd.50365, 2013. 